\title{
Multi-Satellite Data of Land Surface Temperature, Lakes Area, and Water Level for Hydrological Model Calibration and Validation in the Yangtze River Basin
}

\author{
Chiara Corbari ${ }^{1, *}$, Claire Huber ${ }^{2}$, Hervè Yesou ${ }^{2}$, Ying Huang ${ }^{3,4}$, Zhongbo $\mathrm{Su}^{3}$ and \\ Marco Mancini ${ }^{1}$ \\ 1 Department of Civil and Environmental Engineering, Politecnico di Milano, 20133 Milan, Italy; \\ Marco.mancini@polimi.it \\ 2 ICube-SERTIT, 67412 Illkirch-Graffenstaden, France; claire.huber@sertit.u-strasbg.fr (C.H.); \\ herve.yesou@unistra.fr (H.Y.) \\ 3 Faculty of Geo-Information Science and Earth Observation., University of Twente, \\ 7522 Enschede, The Netherlands; yhuang@sklec.ecnu.edu.cn (Y.H.); z.su@utwente.nl (Z.S.) \\ 4 State Key Laboratory of Estuarine and Coastal Research, East China Normal University, \\ Shanghai 200241, China \\ * Correspondence: chiara.corbari@polimi.it
}

Received: 15 October 2019; Accepted: 7 December 2019; Published: 12 December 2019

check for updates

\begin{abstract}
This study shows the feasibility of the combined use of multi-satellite data and an energy-water balance model for improving the estimates of water fluxes over time and distributed in space in the Yangtze River basin. In particular, a new methodology is used to constrain an internal model variable of the distributed hydrological model based on the satellite land surface temperature. The hydrological FEST-EWB model (flash flood event-based spatially distributed rainfall-runoff transformation-energy water balance model) with its energy-water balance scheme allows to continuously compute in time and distributed in space soil moisture and evapotranspiration (ET) fluxes thanks to a double link with satellite-derived data as input parameters (e.g., LAI) and as variables for model states' updates as the land surface temperature (LST). This LST was used to calibrate the model soil parameters instead of using only dedicated ground measurements. The effects of the calibration procedure were evaluated at four available river cross-sections along the Yangtze River, considering also the presence of the Three Gorges Dam. Flow duration curves were also considered to understand the volume storages' changes. The Poyang and Dongting Lakes dynamics were simulated from FEST-EWB and compared against satellite water extended from MERIS and ASAR data and water levels from LEGOS altimetry data (Topex/Poseidon). The FEST-EWB model was run at $0.009^{\circ}$ spatial resolution and three hours of temporal resolutions for the period between 2003 and 2006. Absolute errors on LST estimates of $3{ }^{\circ} \mathrm{C}$ were obtained while discharge data were simulated with errors of $10 \%$. Errors on the water area extent of $7 \%$ and on the water level of $3 \%$ were obtained for the two lakes.
\end{abstract}

Keywords: distributed energy water balance model; satellite land surface temperature; lake dynamics; discharge

\section{Introduction}

A more precise estimate of water resources nowadays has a fundamental role for different scientific (hydrology, agriculture, climate change) and operative issues, from flood forecast to drought management, and it is also fundamental to the understanding of the natural and human water cycle [1-3]. The application of traditional hydrological models to large continental river basins is often 
limited by the scarcity of in situ meteorological and discharge data [4] and generally, their calibration and validation rely on the comparison between simulated and observed discharges, which are usually very few [5-7].

Satellite data are then an alternative to ground information guaranteeing in some cases, with even higher spatial and temporal resolutions than those from ground measures [8-12]. Hence, the integrated use of multi-satellite data and distributed hydrological models based on energy-water balances is an important step ahead for a more precise quantification and verification of evapotranspiration (ET) and soil water content (SM) at the watershed and irrigation district scales, as quoted in the literature over the last decades [13-20]. Satellite data have also been used for calibrating the parameters of distributed hydrological modes. For example, Immerzeel and Droogers [21] used evapotranspiration from the MODIS satellite, Campo et al. [22] soil moisture from ERS-2 radar images, Rientjes et al. [23] evapotranspiration from MODIS and streamflow, and Wanders et al. [24] discharge and AMSR-E, SMOS, and ASCAT soil moisture.

In particular, satellite images of land surface temperature (LST), which are usually used as input data for ET calculation [25-28], can also be used to constrain the parameters of hydrological models if the latter are based on energy and water balance equations. The authors of Caparrini et al. [13] calibrated the variable infiltration capacity (VIC) model using satellite LST and ground discharge measures; Gutmann and Small [29] calibrated the soil hydraulic properties of the NOAH land surface model with satellite LST; Corbari and Mancini $[30,31]$ used satellite LST for a pixel-wise calibration of soil and vegetation parameters of the FEST-EWB energy water balance model as a complementary technique to local discharge data.

Satellite information can also be a valuable tool for studying lakes dynamics, and measuring water levels and area $[32,33]$. In particular, water extent can be measured by visible images thanks to their high spatial resolutions with LANDSAT and SENTINEL2 data, as well as MODIS data thanks to the daily temporal resolution [34-41]. Radar data can also be used to overcome cloud cover issues [42-45]. Nowadays, it is possible for water level to be measured by satellite radar altimetry instruments, and several applications exist [46-51], but these are, however, affected by several limitations especially when used to monitor inland waters. For example, the satellite revisit time from 10 days of Jason-1/2 to 35 days for ERS-1/2, and the low spatial resolution, with measurements only vertical under the satellite which provide the possibility of measuring large width rivers only to avoid measurement of non-water signals. To overcome these problems, some studies have focused on the combined use of hydrological and hydraulic models with remote sensing data to estimate the rating curves [33,52-55] or for calibrating hydrological models $[56,57]$ or hydraulic models $[58,59]$.

In this framework, this work contributes to the improvement of numerical models by increasing the accuracy of hydrological processes' simulation and their understanding using multi-satellite data covering a large part of the electromagnetic spectrum and a distributed hydrological energy water balance model at a large continental watershed scale. Hence, the main objective of this paper was to test the potentiality of using satellite LST for the calibration of a distributed hydrological model as a proxy of surface soil moisture, as a complementary technique based on ground discharge measures. The altimetry water level and water lake area were also used for the calibration of the lake dynamics.

The case study is the Yangtze River basin, which represents one of the largest rivers in the world, between 2003 and 2006. The effect of the two big lakes', Dongting and Poyang, dynamics and of the Three Gorges Dam regulation on the Yangtze River was evaluated. A continuous distributed hydrologic model based on energy and water balance equations (FEST-EWB, flash flood event-based spatially distributed rainfall-runoff transformation-energy water balance) [60] was used. FEST-EWB was run at a spatial resolution of $0.009^{\circ}$ and temporal resolution of $3 \mathrm{~h}$.

\section{Study Area and Data}

The case study area was the Yangtze River (Changjiang) basin in China, with a total area of about 1.8 million $\mathrm{km}^{2}$ (Figure 1). The main river length is equal to $6300 \mathrm{~km}$, being the longest river in China 
and the third longest river in the world, with an average discharge of $30,000 \mathrm{~m}^{3} \mathrm{~s}^{-1}$ and a mean annual variation between $8.1 \times 10^{3}$ and $50 \times 10^{3} \mathrm{~m}^{3} \mathrm{~s}^{-1}$. The basin is characterized by a monsoon regime with strong precipitations between April and August, with a maximum between May and June. The mean annual precipitation is about $800 \mathrm{~mm}$. In this period, floods are frequent [39], especially in the last years, leading to increasing attention on human mitigation and control of the Yangtze floods [61-63]. These are particularly affected by the intensification of human activities, such as construction of levees and filling up of the riverbed, as well as climate change. The most recent major flood events are those of 1870, 1931, 1954, 1998, and 2016, and at a lesser level 2004 and 2010.

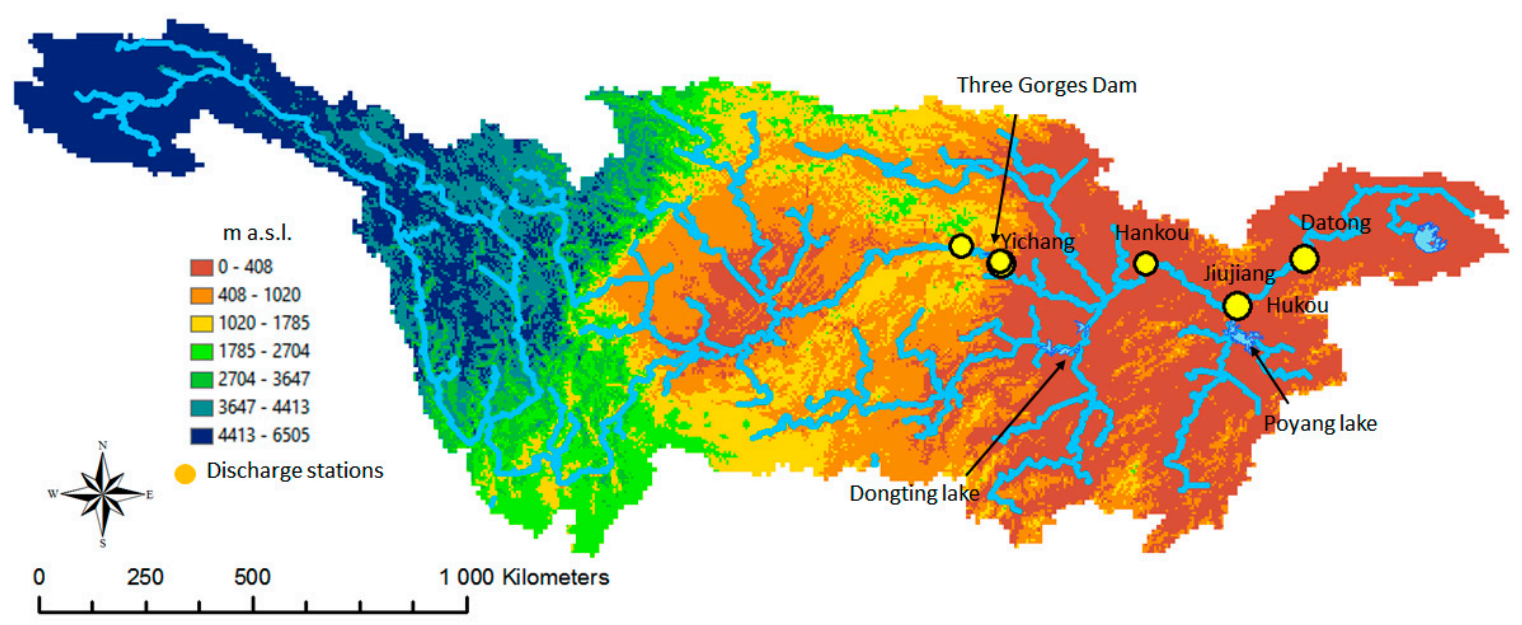

Figure 1. The Yangtze River basin and available discharge stations.

Over the years, a change in the Yangtze River's flow has been experienced due to climate change, but in particular due to the construction of the Three Gorges Dam (TGD) [64-66], which modified the downstream hydrological regime. TGD is one of the world's largest dams, with a storage volume of $39.3 \times 10^{9} \mathrm{~m}^{3}[67,68]$. It has operated from 2003 with a multipurpose use, from flood control to navigation and hydropower generation. Due to its operation, downstream Yangtze level variations were reduced by $3.9 \%$ to $13.5 \%$, with a decrease in fall and an increase in winter and spring $[65,66]$. Moreover, a time shift in the maximum monthly discharge and water levels is evident from August to July at Yichang station.

Another issue that is affecting the water cycle of the Yangtze River basin is the presence of the two big lakes, the Dongting and Poyang Lakes, which are considered as hydrological key components in flood control in the middle Yangtze basin. In fact, the Poyang Lake is the largest freshwater lake of China and is located in the middle reach of Yangtze River, with a mean volume of $143.6 \times 10^{9} \mathrm{~m}^{3}$, which is about $15.6 \%$ of the total flow of the Yangtze River $[69,70]$. Poyang Lake is a dynamic system with very significant seasonal and inter-annual variations in its water levels and area. In fact, during the dry winter period, lake elevation varies between 9 and $18 \mathrm{~m}$ and its area is less than $1000 \mathrm{~km}^{2}$; however, during the summer wet monsoon season, it reaches about $3000 \mathrm{~km}^{2}$. In the last years (2000 to 2016), using remote sensing images, the smallest surface was recorded on 5 January 2012 of about $720 \mathrm{~km}^{2}$ and in February 2004 of about $750 \mathrm{~km}^{2}$; while the largest surface was estimated as about $3400 \mathrm{~km}^{2}$ in June 2002. The average Poyang Lake surface is estimated to be $1850 \mathrm{~km}^{2}$. A considerable inter-annual variation of the minimum lake area was also found to vary between 702.8 and $1259.7 \mathrm{~km}^{2}[39,41,71-73]$. Changes in water extent have also been detected due to climate change and human pressure, with an annual average of $5160 \mathrm{~km}^{2}$ in 1954, which decreased to $3860 \mathrm{~km}^{2}$ in 1992 [69], with a significant decline since 2000 [72,74]. The Dongting Lake is the second largest Chinese water body, which is connected to Yangtze River with four outflows and, similar to Poyang Lake, it acts as a storage basin for the Yangtze floods while during the dry season, it provides water to the river. The lake's area during the dry season is normally less than $500 \mathrm{~km}^{2}$ while it may increase to $2500 \mathrm{~km}^{2}$ in the flood 
season due to the inflow of water from the Yangtze River. During the years, due to sediment transport and human activities, the lake area has diminished from 6000 to $2623 \mathrm{~km}^{2}$ from the 1940s [38,39,75-78].

\subsection{Hydrological and Meteorological Data}

Discharge measurements are available from 2000 to 2006 at Yichang station, which is downstream of the Three Gorges Dam at Hankou, covering the middle Yangtze River basin downstream of Dongting Lake, at Jujiang just upstream of Poyang Lake, and Datong in the lower Yangtze River basin during 2006 (Figure 1). Datong, which is $640 \mathrm{~km}$ away from the estuary, is the upper limit of the tides' influence. The data were collected from the Changjiang Water Resources Commission, China (available in www.cjh.com.cn).

Three Gorges Dam's levels, and incoming and outflowing discharge are provided daily by the China Three Gorges Corporation. Poyang Lake's water levels are available at Duchang ground station (in the middle of the lake) for five days in 2016.

Meteorological data of the air temperature, rainfall, air relative humidity, incoming shortwave radiation, and wind speed are available every $3 \mathrm{~h}$. The forcing dataset used in this study was developed by the Data Assimilation and Modeling Center for Tibetan Multi-spheres, Institute of Tibetan Plateau Research, Chinese Academy of Sciences [79] by merging ground and satellite data and reanalysis data.

\subsection{Soil Type, Land Use, and Hydraulic Properties}

The digital elevation model is available from the U.S. Geological Survey's (USGS) EROS Data Center at 30 arc-second, allowing the resampled resolution of $1 \mathrm{~km}$ to be computed in the flow directions, slope, and aspect.

The pedologic characteristics of soils were available to the authors from the Harmonized World Soil Database (HWSD) [80]. However, for the Yangtze River basin, only three main classes were identified: The soil texture is predominantly $94.5 \%$ in the sandy clay loam class while only $2 \%$ is sand and $3.5 \%$ is clay. From this available basic thematic layer, hydraulic soil parameters required for the application of the hydrological model were derived using the well-known database of [81]. These included the saturated hydraulic conductivity, residual and saturated soil moisture, pore size distribution index, wilting point, field capacity, and Brooks-Corey index.

The ESA Globcover Land Cover [82] was used for the land cover map with 22 land cover types. The information coverage period was between 2005 and June 2006 at the spatial resolution of $300 \mathrm{~m}$ from the MERIS satellite. The minimum stomatal resistance (rsmin), a FEST-EWB parameter that regulates evapotranspiration, was defined for each type of vegetation from this map.

\subsection{Satellite Data}

\subsubsection{Vegetation Parameters}

The 8-day composite period MODIS LAI product was used to retrieve the leaf area index (LAI) maps while the MCD43B3 product was used to derive albedo starting from the directional hemispherical reflectance (black-sky albedo) at the local solar noon and bihemispherical reflectance (white-sky albedo). Both data were obtained at a spatial resolution of $1 \mathrm{~km}$, and images were taken every 16 days (http://ladsweb.nascom.nasa.gov/index.html).

\subsubsection{Land Surface Temperature}

MODIS LST daily L3 global 1-km sin grid v004 data from TERRA satellite were used to retrieve land surface temperature data. The data are available at a spatial resolution of $1 \mathrm{~km}$. The whole basin is covered by three swaths and the west mountainous area has more than three-fold and six-fold more images of the central area and downstream valley. This is due to the higher presence of clouds in the eastern part of the basin, especially during the summer periods during the monsoon. 
A total of 183 images were considered after discarding cloudy images with more than $50 \%$ of the area during the year 2003 for the calibration phase and 301 during 2006 for the validation phase.

\subsubsection{Lake Water Extent}

Over Poyang Lake, and at a lesser level Dongting Lake, a comprehensive remote sensing database was created during the ESA-DRAGON projects [39,71,83], which contains more than 750 medium- and high-resolution satellite images, both optical and SAR. Medium-resolution products correspond to the period analyzed in this paper to the optical MERIS, $3000 \mathrm{~m}$ of spatial resolution, 15 bands covering visible and near infra reed spectral domain, and SAR Wide Swath Mode, C band, HH polarization, spatial resolution $75 \mathrm{~m}$, and both on-board the Envisat satellite. ENVISAT data orthorectification is based on optical high-resolution (HR) data from SPOT, Landsat, Chris-Proba, ALOS, and AVNIR, which were used as a ground reference [42].

The low backscattering characteristic of water in ENVISAT ASAR data, usually appearing in dark tones on SAR images, was exploited to enable an initial water extraction through pixel-based thresholding. Therefore, in the case of windy conditions or partially submerged vegetation, the backscattered signal can be affected, thus presenting higher backscattering values. In these cases, the water layer was manually corrected by the operator. In addition, the multitude of points with strong backscatter associated with the high number of large ships entering and leaving the lake as well as the few thousand vessels working in sand dredging and transporting were corrected too [84-86].

For MERIS Level 1 and Level 2 products, two methods were used jointly to extract water bodies from MERIS Level 1 products, according to the hydrological period. During low water-level periods, a single threshold using band 14 (near infrared) was performed. During high water-level periods, an NDVI mean was used to extract water bodies through thresholding. A single threshold, using either band 10 or band 13 (near infrared), was used to extract water bodies from all MERIS Full Resolution (FR) Level 2 products. These methods have been proven to have the best performances. In fact, to assess and validate water extent extraction, particular attention was paid to the data quality: The assessment of water extent synergy derived from the multi-resolution dataset and the impact of meteorological conditions. Statistical analysis of the ENVISAT water extent comparison showed that ENVISAT ASAR WSM and MERIS data are very concordant for water recognition. However, MERIS optical data tend to see generally more water than ASAR WSM data [85]. This could depend on the fuzzy limits between water and very wet areas. However, visual comparison of water bodies' boundaries extracted from ENVISAT GMM, WSM, and MERIS showed that the external limits are very concordant. Major differences are observed within large water bodies and correspond to alluvial terraces lining the delta's braided streams. Thus, these differences are essentially due to the resolution. Based on the Beijing-1 time series, it was possible to validate the ENVISAT database's general coherency and moreover, synergy between water bodies extracted from ENVISAT ASAR and MERIS data were considered as effective $[43,82]$.

\subsubsection{Altimeter Water Level}

Water level data of both lakes were sourced from Topex/Poseidon along track altimeter data from the Géodésie Océanographie et Hydrologie Spatiales (GOHS) team at Laboratoire d'Etudes en Géophysique et Océanographie Spatiales (LEGOS) in France. It is freely available from LEGOS [50] (http://www.legos.obs-mip.fr/en/soa/hydrologie/hydroweb/). The measurements were performed at $10 \mathrm{~Hz}$, and a virtual station along the river was identified within a selected window where at least two measurements are taken for each repeat cycle. The observations were then averaged to calculate the mean water level and the associated uncertainty was provided as the standard deviation.

\section{Methodology: FEST-EWB Distributed Hydrological Model}

FEST-EWB is a distributed hydrological energy water balance model [60] and it is developed starting from the FEST-WB $[17,86]$. In particular, FEST-EWB has been proven to provide accurate 
predictions of actual evapotranspiration against energy and mass exchange measurements acquired by an eddy covariance station [60] and also at the agricultural district scale against ground and remote sensing information [87], but also at the basin scale against satellite LST and ground discharge measurements for the Po River basin and for the Upper Yangtze River basin $[30,80,88]$.

FEST-EWB computes the main processes of the hydrological cycle and the hydraulic routing through the river network also considering the effects of hydraulic structures as diversion channel reservoirs and retention basins. In particular, the FEST-EWB model with its energy-water balance scheme allows continuously computation in time and distributed in space of soil moisture and evapotranspiration fluxes, solving the system of energy and mass balance equations in terms of a representative equilibrium temperature (RET). This is the land surface temperature, which closes the energy balance equation and rules the fluxes of energy (latent and sensible heat) and of water mass for any pixel of coordinates, $i$ and $j$, of the river basin surface. This modeled RET is then comparable with the satellite LST, allowing the model to be controlled from remote sensing using the same variable detected from remote sensors. This LST may also be used to calibrate the model's soil parameters instead of using only dedicated ground measurements.

The core of the model is the system between the water and energy balance equations, which are linked through evapotranspiration:

$$
\begin{aligned}
& \frac{\partial S M_{i, j}}{\partial t}=\frac{1}{d z_{i, j}}\left(P_{i, j}-Q_{i, j}-D r_{i, j}-E T_{i, j}\right) \\
& R n_{i, j}-G_{i, j}-H_{i, j}-L E_{i, j}=\frac{\Delta W}{\Delta t} i_{i, j}
\end{aligned}
$$

where $i$ and $j$ are the pixel coordinates, $P$ is the precipitation $\left(\mathrm{mm} \mathrm{h}^{-1}\right), Q$ is the runoff $\left(\mathrm{mm} \mathrm{h}^{-1}\right), D r$ is the percolation $\left(\mathrm{mm} \mathrm{h}^{-1}\right), E T$ is the evapotranspiration $\left(\mathrm{mm} \mathrm{h}^{-1}\right), z$ is the soil depth $(\mathrm{m}), R n\left(\mathrm{~W} \mathrm{~m}^{-2}\right)$ is the net radiation, $G\left(\mathrm{~W} \mathrm{~m}^{-2}\right)$ is the soil heat flux, $H\left(\mathrm{~W} \mathrm{~m}^{-2}\right)$ and $L E\left(\mathrm{~W} \mathrm{~m}^{-2}\right)$ are respectively the sensible heat and latent heat fluxes, and $\Delta W / \Delta t\left(\mathrm{~W} \mathrm{~m}^{-2}\right)$ encloses the energy storage terms. These fluxes were computed following the equations described in [60] as functions of the soil and vegetation parameters, which were calibrated against observed LST.

A diffusion wave scheme based on a non-linear and time variable celerity Muskingum-Cunge method was used for the runoff routing computation throughout the hillslope and river network. The runoff formation was defined based on a modified SCS-CN method adapted to work in continuous simulations [89] by updating the potential maximum retention cell by cell at the beginning of rainfall as a linear function of the degree of saturation.

Reservoir flow routing was based on the continuity of mass equation:

$$
\begin{aligned}
& Q_{u}(t)=Q_{u}(t, V(t)) \\
& Q_{e}(t)-Q_{u}(t)=\frac{d V(t)}{d t},
\end{aligned}
$$

where $Q_{u}$ is the outflow discharge $\left(\mathrm{m}^{3} \mathrm{~s}^{-1}\right), \mathrm{t}$ is time, $V$ is the volume $\left(\mathrm{m}^{3}\right)$, and $Q_{e}$ is the inflow discharge $\left(\mathrm{m}^{3} \mathrm{~s}^{-1}\right)$. The second equation was solved with the third-order Runge-Kutta method [90].

The lake area dynamics were computed by comparing the computed water level with the DEM of the pixels surrounding the lakes (starting from the minimum lake area).

The subsurface flow routing calculation was performed with a cascade of linear reservoirs and the time constant (kprof) was computed as the ratio between the volume of each cell divided by the hydraulic transmissivity of the deep soil multiplied by the local slope.

\section{Calibration Methodology with Satellite and Ground Data}

The calibration procedure herein applied follows the idea developed by [30,31]. The procedure is a physically based sequential process starting from soil surface parameters ending in subsurface flow parameters. The first were calibrated by minimizing the differences, pixel by pixel independently from the other, between the modelled representative equilibrium temperature and the satellite land surface 
temperature while the latter were calibrated by minimizing the differences between the observed and simulated volumes at different river cross-sections. This combined calibration procedure was needed to correctly reproduce the different hydrological fluxes. In fact, the superficial processes, especially during dry conditions, are driven by the land surface temperature; which, on the contrary, is not able to solely control the formation of discharges, which is regulated simultaneously by superficial and sub-superficial processes. Moreover, this new procedure allows modification of the hydraulic soil and vegetation parameters in each single pixel independently from one another according to the temperature difference of each pixel, thus guaranteeing the correctness of the spatial definition of the mass and energy fluxes. This is in contrast to the traditional calibration based only on the agreement of the hydrological model discharge with the ground measurements at specific locations (which are usually very few), where the parameters are modified by a single factor for the entire area lumping all the hydrological processes.

Corbari and Mancini [31] performed a sensitivity analysis on the FEST-EWB surface parameters, which have to be calibrated and are sensitive to LST changes, including the soil hydraulic conductivity, Brooks-Corey index, soil depth, minimum stomatal resistance, soil evaporation resistance, and aerodynamic resistance, while for subsurface flow routing, kprof was considered.

The soil and vegetation parameters were modified in each single pixel independently from one another according to the matrix of the mean differences between the satellite land surface temperature and modeled representative equilibrium temperatures. Hence, the differences in each pixel computed for all the available dates of the satellite data were considered and the parameters were modified according to the mean in time. The parameters were modified following a "trial and error" procedure, meaning that the parameters were firstly modified, then the FEST-EWB was run, the LST differences were computed, and the parameters were modified a second time. The calibration procedure was stopped when the errors were not changing anymore. The parameters were always kept with their physical ranges [81]. Propagation parameters were calibrated by comparing the observed and simulated volumes, which are strongly dependent on the infiltration process, and not linked with the timing of propagation. These parameters were modified following the "trial and error" procedure, but contrary to LST calibration, a single modification factor of the parameter was used for the entire basin closed at each river cross-section.

Lakes dynamics were then calibrated in the FEST-EWB hydrological model by comparing water heights from the satellite altimeter data and the water area from satellite data by modifying the parameters regulating the continuity equation of the reservoirs (Equation (2)). The parameters were modified with the "trial and error" procedure. In this case, each lake was considered to behave independently from one another.

The reliability of the different estimates was evaluated using different statistical indexes, including the mean bias error (MBE), absolute mean bias error (AMBE), and root mean square error (RMSE), which were computed as follows:

$$
\begin{gathered}
M B E=\frac{\sum_{i=1}^{n}\left(X_{s i m}{ }^{i}-X_{o b s}{ }^{i}\right)}{n}, \\
A M B E=\frac{\sum_{i=1}^{n}\left|X_{s i m}{ }^{i}-X_{o b s}{ }^{i}\right|}{n}, \\
R M S E=\left[\frac{\sum_{i=1}^{n}\left(X_{s i m}{ }^{i}-X_{o b s}{ }^{i}\right)^{2}}{n}\right]^{0.5},
\end{gathered}
$$


where $X_{\text {sim }}{ }^{i}$ th is the $i$ th simulated variable by FEST-EWB, $X_{o b s}{ }^{i}$ th is the $i$ th measured variable, $n$ is the sample size, and $\overline{X_{o b s}}$ is the average observed variable.

To quantify the model efficiency, the Nash and Sutcliffe index, $\eta$, was also calculated:

$$
\eta=1-\frac{\sum_{i=1}^{n}\left(X_{s i m}{ }^{i}-X_{o b s}{ }^{i}\right)^{2}}{\sum_{i=1}^{n}\left(X_{o b s}{ }^{i}-\overline{X_{o b s}}\right)^{2}},
$$

where the closer $\eta$ is to 1 , the more accurate the model is.

\section{Results}

The results are reported comparing MODIS LST and FEST-EWB RET at the basin scale, ground and modeled discharge and volume at four river cross-sections, and the lakes' water level and extent from the satellite and FEST-EWB model.

\subsection{Calibration and Validation of Soil Surface Parameters from Satellite Data of LST}

Several simulations were performed with different parameters, minimizing the difference between the observed satellite LST and RET for each pixel and for each data for which satellite data were available. An array of pixel temperatures was provided for any pixel, where each temperature was the one that minimizes the difference with the satellite observation, obtained by tuning the soil parameters. The temporal average temperature for each pixel was assumed as the target temperature that the set of soil parameters reproduced.

In Figure 2, as an example, maps of LST from MODIS and the simulated RET after the calibration procedure are reported for 10 March 2003, 14 July 2003, and 12 November 2003 at 12:30 local time. The mean and standard deviation values were computed for the same number of pixels (e.g., if satellite LST is covered with clouds, FEST-EWB pixels are also masked out). The 10 March 2003 LST from MODIS has a mean value of $9.3^{\circ} \mathrm{C}$ with a standard deviation of $6.7^{\circ} \mathrm{C}$ while the RET values are 10.6 and $7.5^{\circ} \mathrm{C}$, respectively; for 14 July 2003, LST from MODIS has a mean value of $28.4{ }^{\circ} \mathrm{C}$ with a standard deviation of $5.2^{\circ} \mathrm{C}$ while RET values are 29.7 and $6.3^{\circ} \mathrm{C}$, respectively, and for 12 November 2003 LST from MODIS has a mean value of $11.2^{\circ} \mathrm{C}$ with a standard deviation of $3.9^{\circ} \mathrm{C}$ while RET values are 9.8 and $2.5^{\circ} \mathrm{C}$, respectively. 


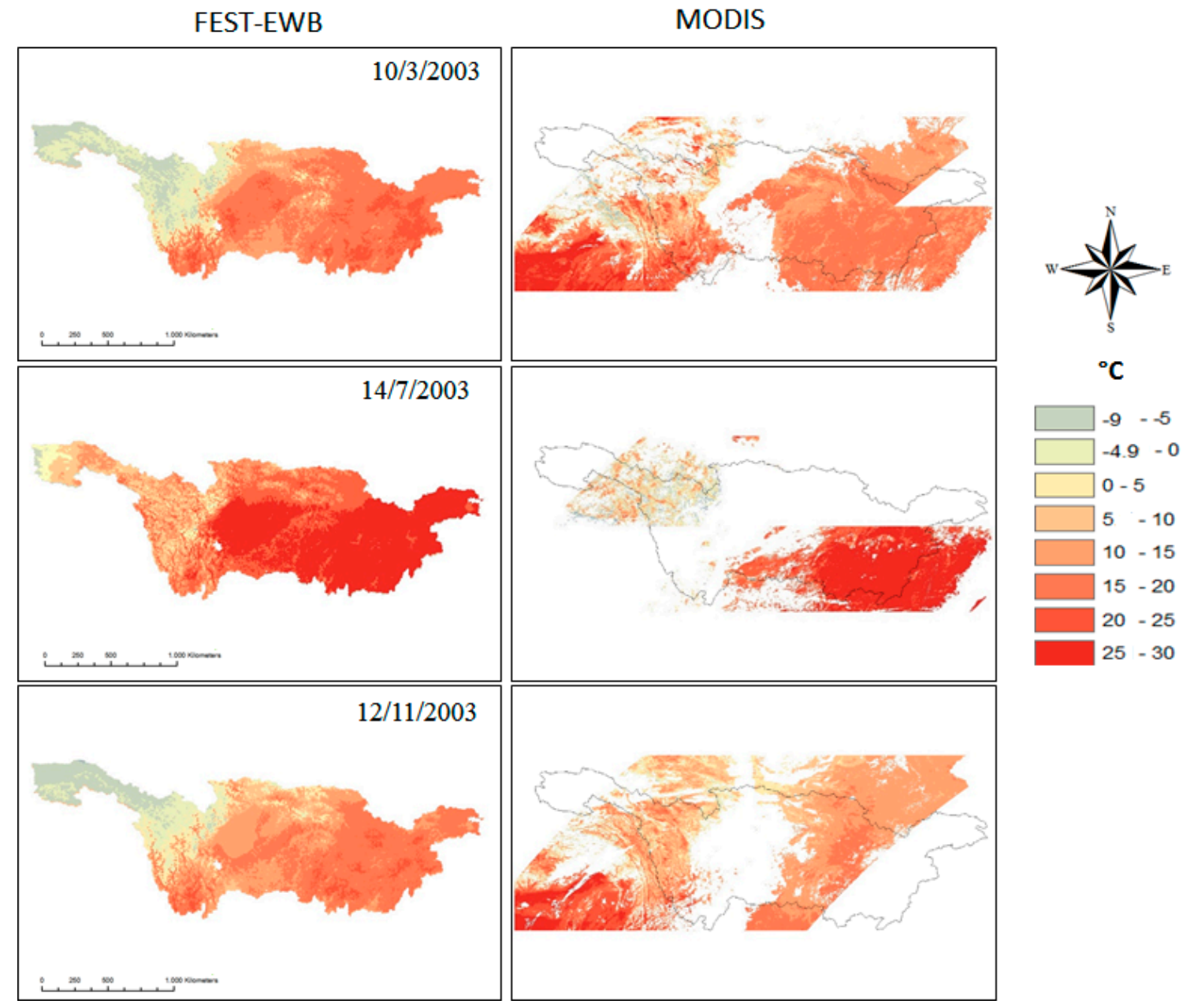

Figure 2. FEST-EWB RET and MODIS LST for 10 March 2003, 14 July 2003, and 12 November at 12:30.

Figure 3 shows the mean difference pixel by pixel between FEST-EWB and MODIS before and after the calibration. Then, considering the entire database, the AMBE is equal to $3.3^{\circ} \mathrm{C}$ after the calibration procedure starting from $9^{\circ} \mathrm{C}$ before the calibration (Figure 3) while the RMSE reaches $3.1^{\circ} \mathrm{C}$ from $9.4^{\circ} \mathrm{C}$. More specifically, a sensible difference is present between winter and summer time. In fact, higher discrepancies were obtained during the winter period, with mean errors after the calibration of about $-6{ }^{\circ} \mathrm{C}$ while during summer, the mean error is $2.5^{\circ} \mathrm{C}$. This is probably due to the difficulties in simulating the snow coverage and radiation diffusion at high elevation. In fact, if only the area below $2000 \mathrm{~m}$ a.s.l. is considered, a mean difference of $-2^{\circ} \mathrm{C}$ is obtained while the area above $2000 \mathrm{~m}$ a.s.l. shows a mean difference of $-7^{\circ} \mathrm{C}$. This discrepancy is in any case reduced to $-3^{\circ} \mathrm{C}$ during summer. In Figure 3 , the mean values of the MODIS and FEST-EWB land surface temperature are also shown for the year 2003 after the calibration procedure, confirming the goodness of the simulation. 

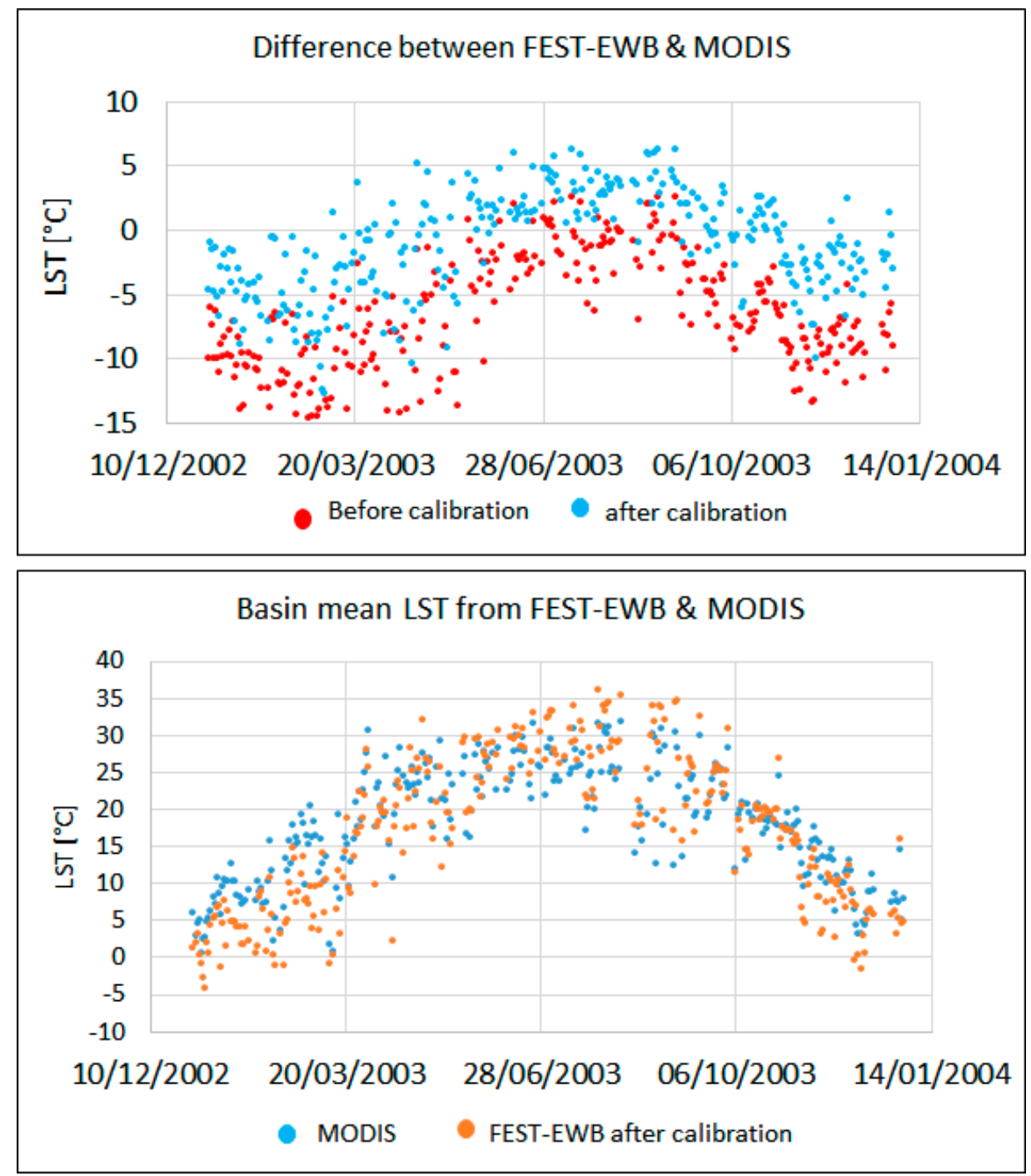

Figure 3. Mean difference pixel by pixel between FEST-EWB and MODIS before and after the calibration (up); basin mean of the MODIS and FEST-EWB land surface temperature after parameter calibration (bottom).

The Yangtze River basin is characterized by very high heterogeneity due to its large areal extension. So, to better explain the thermodynamics behavior of the different land covers, the catchment was divided into homogeneous areas considering the ESA Globcover Land Cover. MBE and AMBE were then computed for four groups: Woods, crops, pasture and brushes, and water. Urban areas were not considered. From this analysis, good agreement was obtained for the wood areas, with lower errors around $1{ }^{\circ} \mathrm{C}$ due to better identification of the vegetation parameters of these areas. Similar results were obtained for the water areas. Instead, crop areas have higher errors, with an MBE of $3.4^{\circ} \mathrm{C}$, mainly due to the lack of irrigation information. High errors were also found for the pasture and brushwood area, which are mainly located at high altitudes, with a mean value of $-5^{\circ} \mathrm{C}$.

These differences in terms of spatial distribution due to elevation and land cover are immediately visible if the maps of the mean absolute difference between RET and MODIS LST over 183 images are analyzed. In Figure 4, the highest differences are in fact found in the West Yangtze basin, where high elevations are reached (7000 $\mathrm{m}$ a.s.1.). In general, $76 \%$ of the pixels have a mean difference below $3{ }^{\circ} \mathrm{C}$, confirming the overall agreement between the observed and modelled temperatures; $1.9 \%$ have values over $7^{\circ} \mathrm{C}$. 

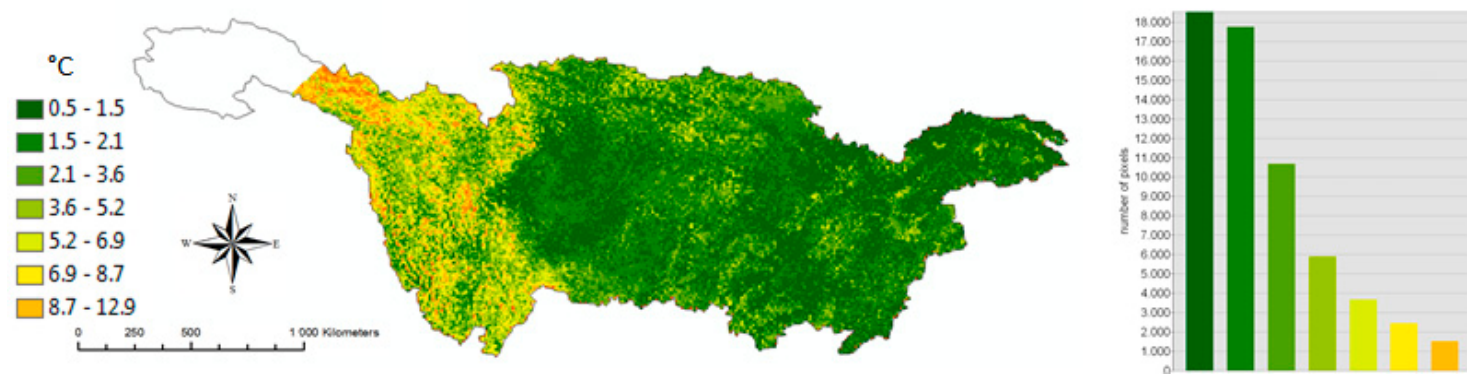

Figure 4. Map of the absolute difference pixel by pixel between all the MODIS and FEST-EWB land surface temperatures in the calibration phase.

In Figure 5, an example of three parameters of the FEST-EWB model are shown before and after the calibration process. The maps, in addition to obviously showing a variation in the single values (remaining within the valid ranges as reported in [81]), also denote increased spatial variability due to the applied pixel-wise calibration methodology.

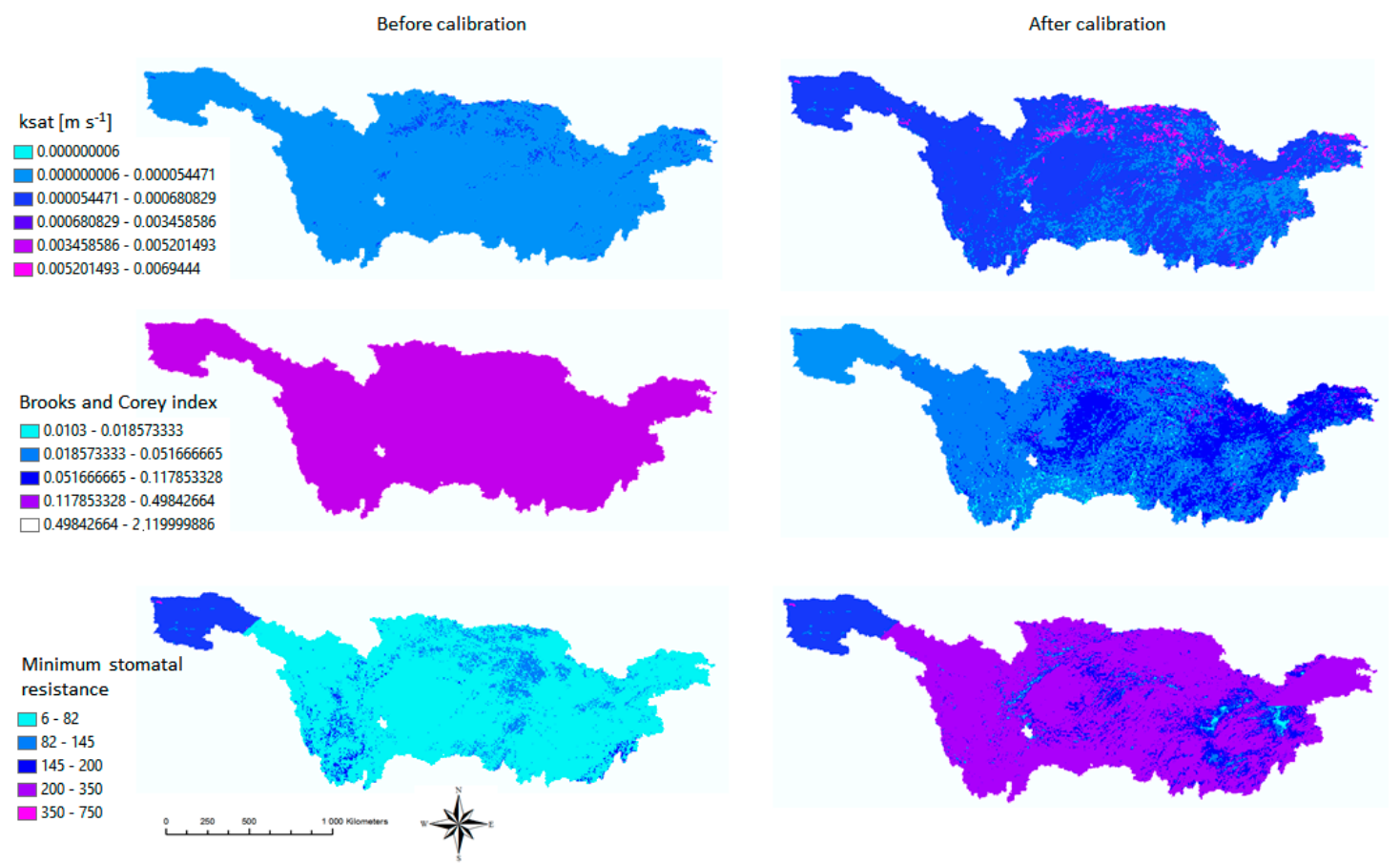

Figure 5. Example of FEST-EWB parameters before and after the calibration process.

This procedure was then validated during the year 2006 against 301 LST images (Figure 6). Using the original parameter values before the calibration, a spatial mean error computed pixel by pixel of $5.04{ }^{\circ} \mathrm{C}$ was obtained while a value of $2.3^{\circ} \mathrm{C}$ was reached using the calibrated parameters. As for the calibration phase, higher discrepancies were obtained during the winter period, with mean errors of about $4{ }^{\circ} \mathrm{C}$ after the calibration, while during summer, the mean error was around $1^{\circ} \mathrm{C}$. 

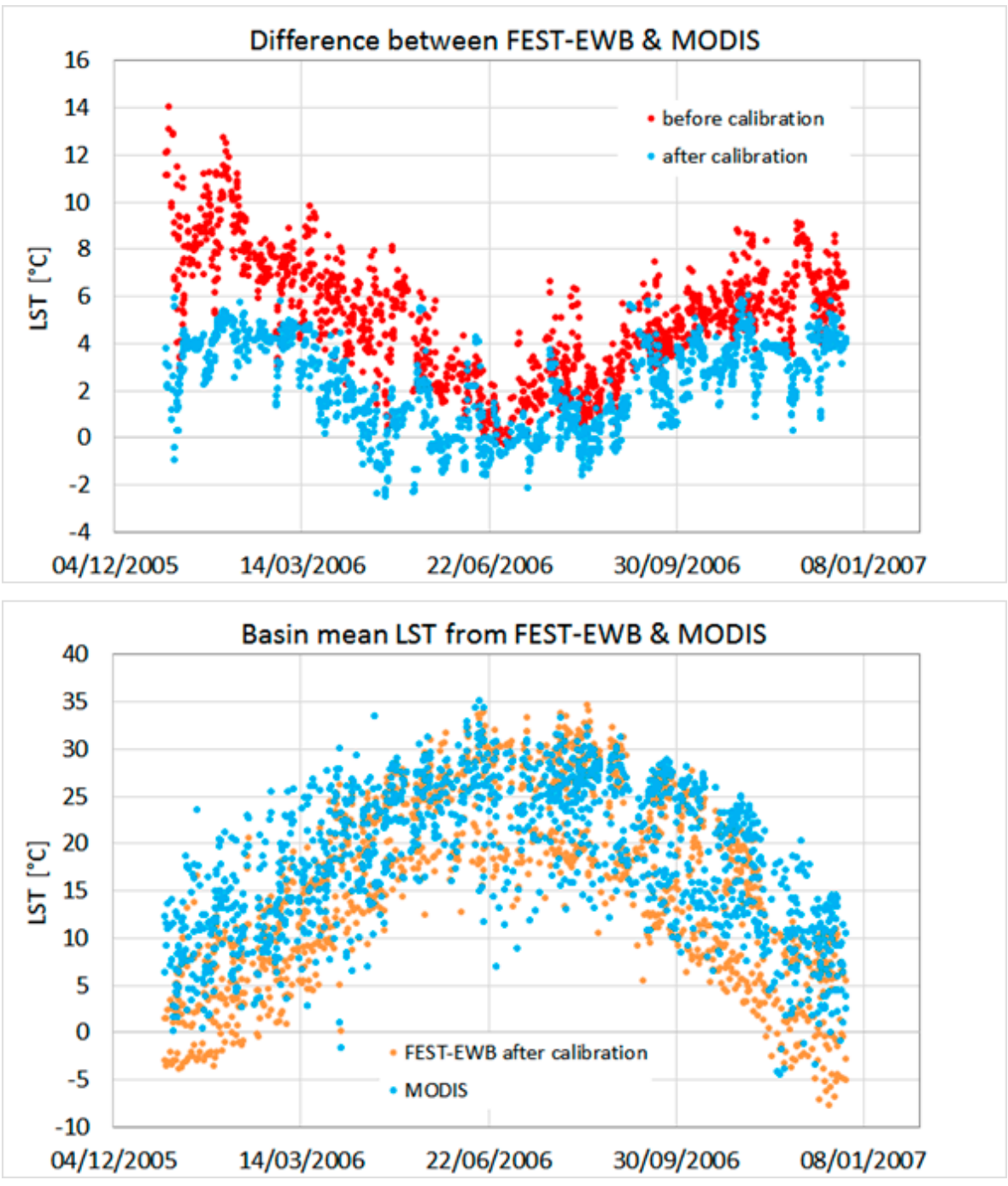

Figure 6. Mean difference pixel by pixel between FEST-EWB and MODIS before and after the calibration (up); basin mean of the MODIS and FEST-EWB land surface temperature for the validation period (bottom).

\subsection{Calibration and Validation of Lake Dynamics from Satellite Altimeter and Water Surface Extension}

The Poyang and Dongting Lakes' areas, as previously described, change considerably during the year, especially due to the monsoon season. The dynamics of these two lakes was modelled by calibrating the outflow discharges equation, minimizing the differences between the LEGOS altimeter data and simulated water level, and controlling the water surface extension as detected from MERIS and ASAR images.

MERIS and ASAR images were classified to infer water surface along the years (Section 2.3.3) and then compared to FEST-EWB estimates. In Figure 7, the water extents are reported for Poyang Lake, showing good agreement between the mean values. A mean absolute difference of $380 \mathrm{~km}^{2}$ was obtained with the model, which generally underestimates the observed images. FEST-EWB simulations were able to correctly reproduce observed data with a relative error of $6 \%$. During the analyzed period, a maximum area of about $3000 \mathrm{~km}^{2}$ and a minimum of about $500 \mathrm{~km}^{2}$ were found, which is in accordance with literature values $[39,71,91,92]$. 

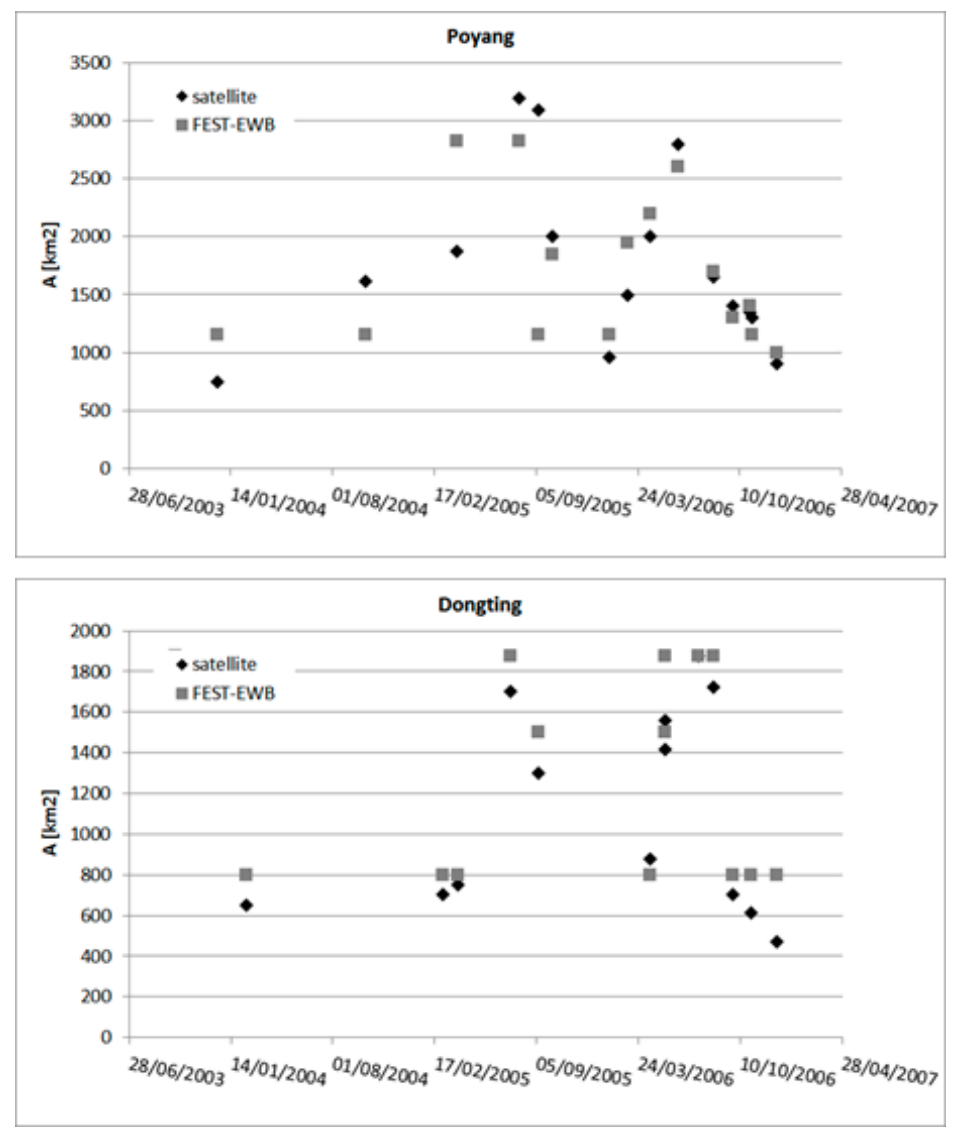

Figure 7. Lakes' area from satellite data and from the FEST-EWB model for Poyang (up) and Dongting (down) Lakes.

To confirm the ability of FEST-EWB simulations to correctly reproduce observed data, in Figure 8, as an example, a comparison between the observed ASAR, MERIS, and simulated lakes area is reported for different dates along the year: 12 March 2006, 21 May, 25 June, 23 August, and 19 October 2006. Lake shrinkage is clearly visible, with a much larger area during summer than winter. A good shape agreement was obtained among the different images, especially between FEST-EWB and ASAR. 

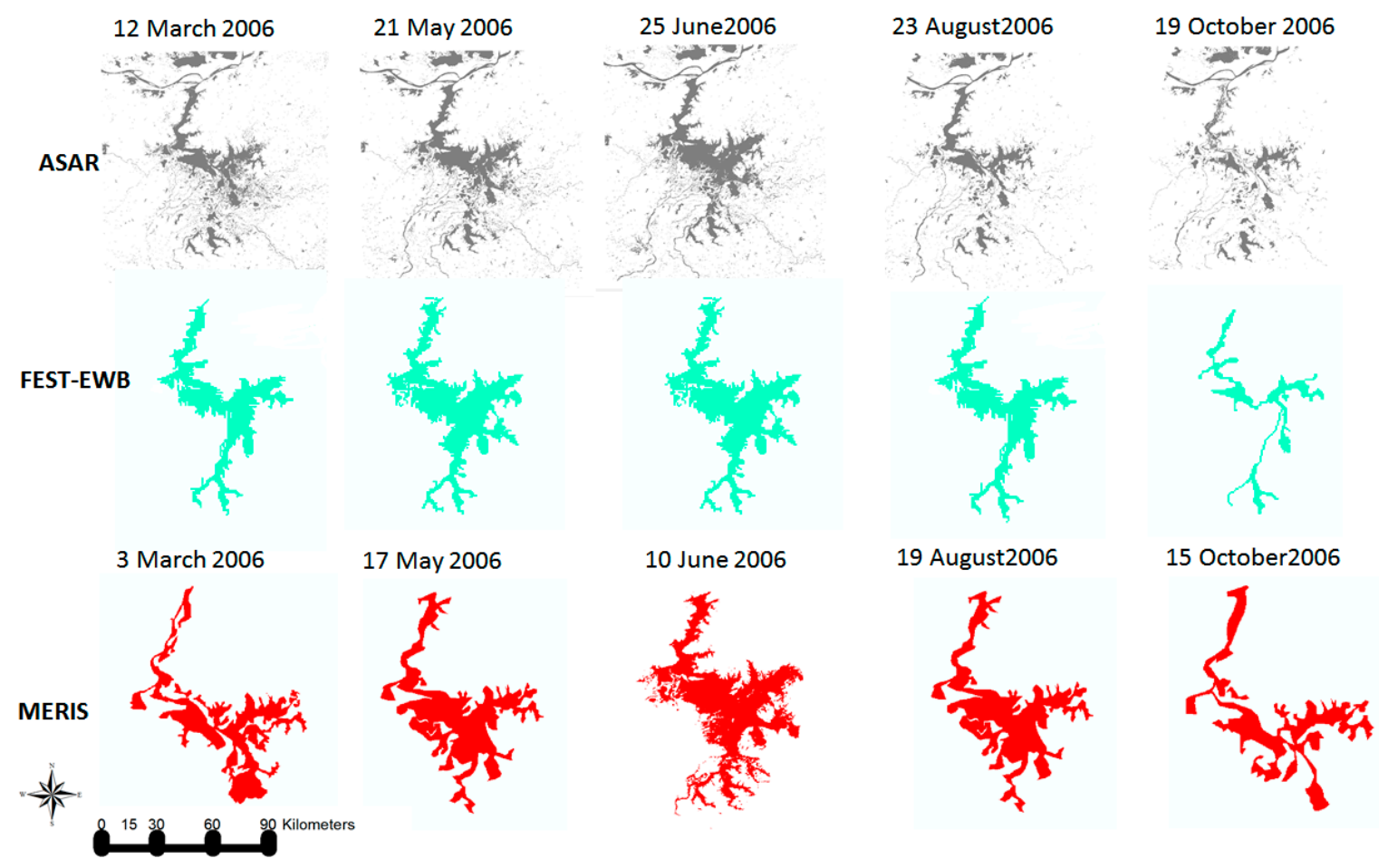

Figure 8. Comparison between observed ASAR, MERIS, and simulated FEST-EWB lake area for Poyang Lake.

Similar results were obtained for Dongting Lake, as shown in Figure 7, with a mean absolute difference of $150 \mathrm{~km}^{2}$ with FEST-EWB overestimation, leading to a relative error of $9 \%$. A maximum area of about $2500 \mathrm{~km}^{2}$ and a minimum of $500 \mathrm{~km}^{2}$ were obtained. In Figure 9, the MERIS and FEST-EWB model areas are compared for 21 July and 21 December 2006, showing similar shapes.

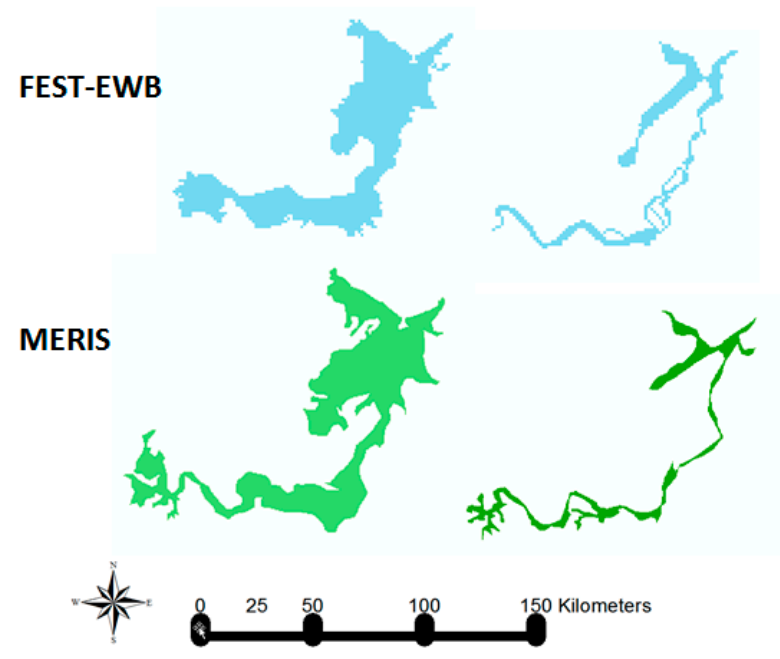

Figure 9. Comparison between observed ASAR, MERIS, and simulated FEST-EWB lake area for Dongting Lake.

These analyses should be discussed considering that 2006 was a dry year due to a deficit of rainfall, especially in the upper Yangtze basin, which lead to the beginning of Poyang Lake shrinking in mid-August when normally it would begin in mid-September. 
Simulated water levels for both lakes were then compared with the observed data from the satellite altimeter. The comparison is reported in Figure 10, showing good agreement between the two series, confirming the ability of the FEST-EWB model to reproduce the dynamics of filling and emptying of the lakes. A relative error equal to $-3.6 \%$ was obtained for Poyang Lake, with water height dynamics ranging between a maximum of about $15 \mathrm{~m}$ and a minimum of $9 \mathrm{~m}$. An error equal to $3 \%$ was obtained for Dongting Lake, which oscillates between $31 \mathrm{~m}$ during the rainy season to $25 \mathrm{~m}$ in the dry season. The comparisons were performed from June 2003, after a spin-up period of the hydrological model. The obtained errors should also be considered in relation to the altimeter errors, where a standard deviation is provided with the data and reported in Figure 10. For Poyang Lake, the altimeter a mean standard deviation on the measured level of $0.43 \mathrm{~m}$, with a maximum value of $1.25 \mathrm{~m}$; while on Dongting Lake, the mean standard deviation is $0.14 \mathrm{~m}$ with a maximum value of $0.7 \mathrm{~m}$.

The FEST-EWB model was then validated against the few available ground data in Poyang Lake. The results shown in Figure 10 confirm the good model performances, with a mean difference of $0.06 \mathrm{~m}$ and an absolute difference of $1.1 \mathrm{~m}$.
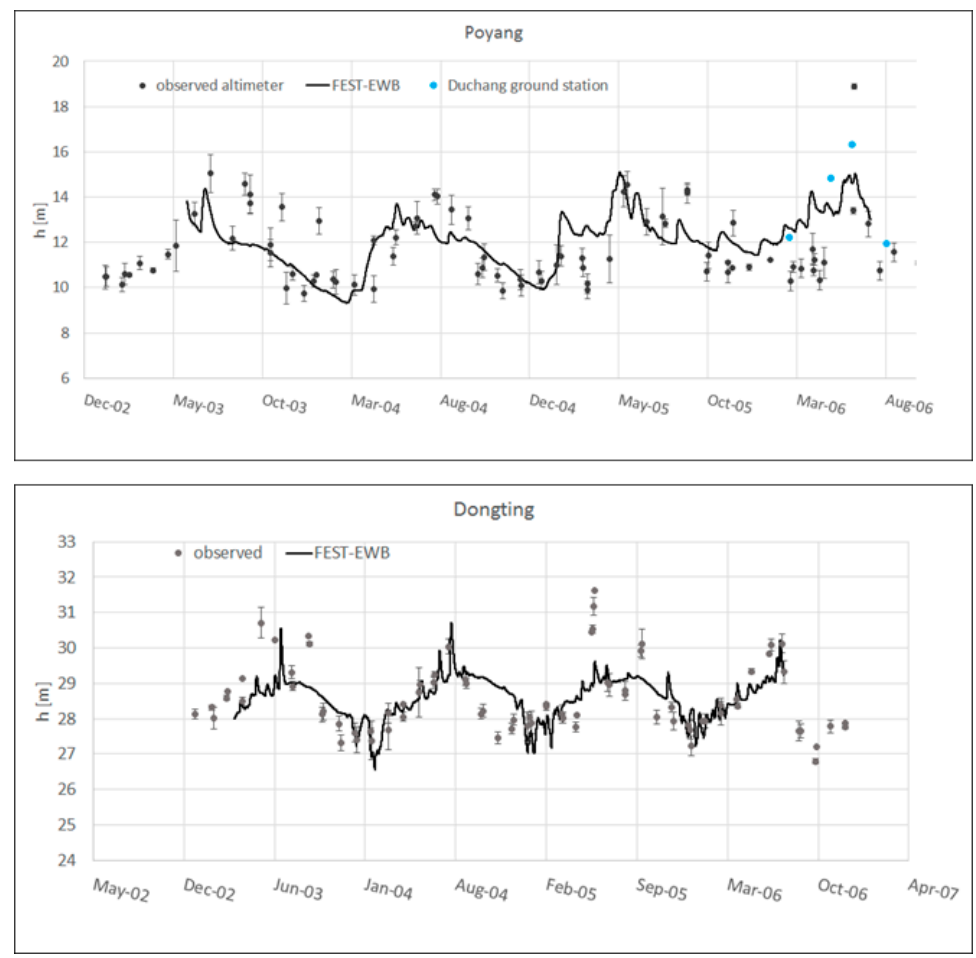

Figure 10. Comparison between observed and simulated water levels for Poyang (up) and Dongting (down).

\subsection{Calibration of Base Flow Parameters from Ground Discharge Data}

Yichang station was calibrated from 2003 to 2004 and 2006 (Figure 11). The Three Gorges Dam was implemented into the FEST-EWB model by solving the continuity equation to compute the dam outflow. Starting from the available observed water level, inflow and outflow data for some days between 2003 and 2009, a regulation policy, based on keeping a fix water level into the lake, was implemented into the hydrological mode. Before calibration, the FEST-EWB model sensibly underestimated the observed volume while after the calibration, a generalized improvement was observable in terms of errors ranging from $-27.9 \%$ to $-7.3 \%$, and the Nash and Sutcliff index, which improved from 0.34 to 0.6 after calibration. 

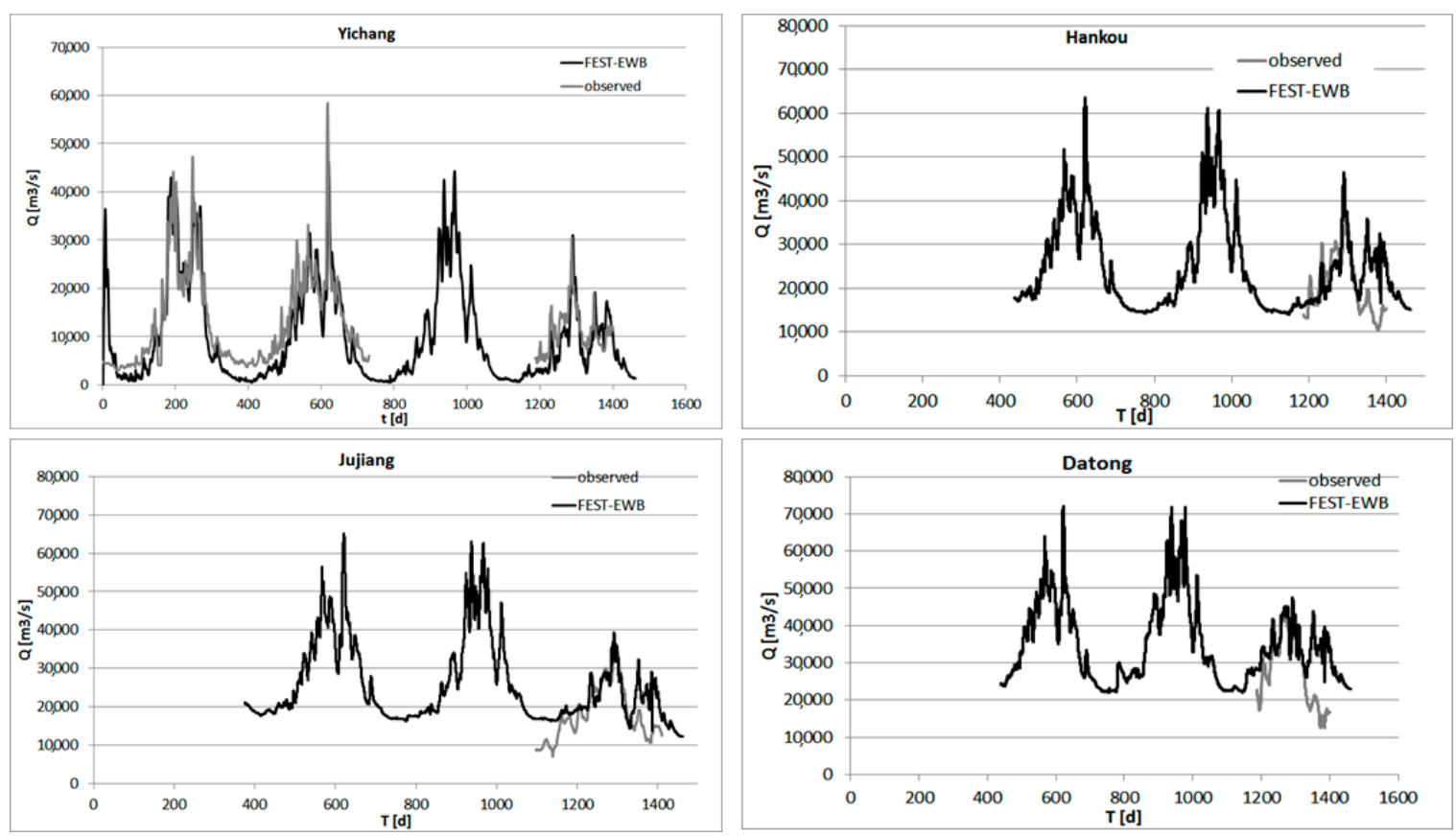

Figure 11. Measured and simulated discharges at Yichang and Hankou, Datong, Jujiang (time is reported in Julian days from 2003 to 2006).

In Figure 11, results are also reported for the other three stations. At Hankou River cross-section, the observed ground discharge values were only available for 2006, and the Nash and Sutcliff index is equal to 0.72 while the error on the observed and simulated cumulated volume is equal to $16 \%$. Similar results were obtained downstream at the other two available cross-sections of Datong and Jujiang. In particular, at Jujiang station, just upstream of the confluence of Poyang Lake, there is good agreement between the observed and simulated discharges and volumes, with a Nash and Sutcliff index of 0.71 and an error of $10 \%$ on the cumulated volume. Instead, at Datong station, for 2006, the Nash and Sutcliff index is equal to 0.42 while the error on the observed and simulated cumulated volume is equal to $26 \%$. This lower agreement in Datong station, which is located downstream of the confluence of Yangtze River with Poyang Lake's outlet, is probably due to errors on the Poyang Lake simulation. This is also evident in Figure 9, where the FEST-EWB model also overestimates the lake water level. This difficulty can also be explained by the behavior of Poyang Lake on Yangtze River, the outflow of which is blocked during the flood season, thus modifying the lake and river interaction $[69,92]$.

Moreover, to quantify in an engineering way the available water along the Yangtze River, flow duration curves were then estimated at the different river cross-sections. In Figure 12, these are reported for the four analyzed river cross-sections, showing good accordance between the observed and simulated data, except for Datong station at low discharge. It is then possible to notice that the year 2006 is a drier year compared to 2003 and 2004, with less available water at Yichang station. 

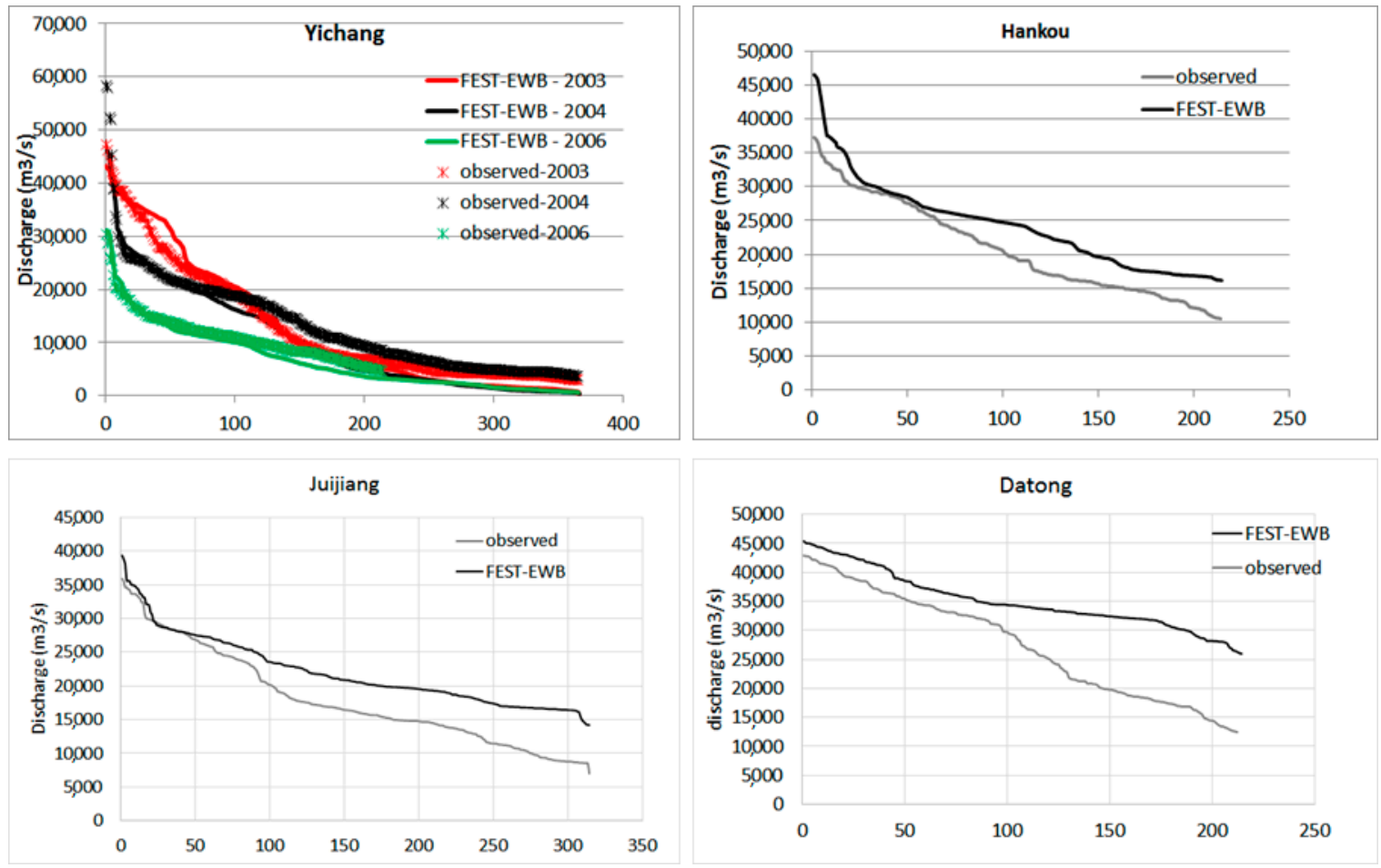

Figure 12. Flow duration curves at Yichang and Hankou stations.

\section{Discussion and Conclusions}

The paper showed the feasibility of the combined use of multi-satellite data and an energy-water balance model in providing better estimates of water fluxes over time and distributed in space.

The strength of the procedure applied in this paper is its calibration and validation based on several different independent measurements (e.g., remotely sensed LST, lake altimetry and water extent, and ground-measured discharges), which are used to control different interconnected hydrological processes in the FEST-EWB model.

The use of satellite land surface temperature as a proxy of the mass balance accuracy [93] was studied, showing the feasibility of using the modelled equilibrium land surface temperature RET to calibrate the distributed hydrological model, allowing modification of the soil hydraulic and vegetation parameters in each pixel independently from one another. This means there is no reliance on only the discharge/volume data measured at a few available river cross-sections. In fact, the FEST-EWB model was calibrated against MODIS LST, obtaining an AMBE equal to $3.3^{\circ} \mathrm{C}$ and an RMSE equal to $3.1^{\circ} \mathrm{C}$. These results have to be analyzed considering the uncertainty of the satellite LST data, especially in heterogeneous areas, considering their spatial resolution, scan angle of view of the sensor, and emissivity [94], as well as the cloud coverage, which is an important issue in the Yangtze River during the monsoon season. The MODIS LST product has an AMBE with respect to ground data of $2 \mathrm{~K}$ [95], which is similar to the differences obtained in this paper between satellite LST and FEST-EWB RET. Similar results have also been obtained for the same model over an agricultural field [60,87] and also for the Po River basin [30]. Comparable results were also found for other land surface models. For example, in the Global Atmosphere/Land 6.1 [96], LST biases versus MODIS LST of -3.6 K were obtained while the Jules model [97] errors against satellite LST from AATSR, MODIS, and SEVIRI ranged between 7 and $1 \mathrm{~K}$ in different months and homogeneous to heterogeneous areas.

Satellite LST data were preferred instead of satellite soil moisture data. Despite their potential in providing direct soil moisture measurement and overcoming cloud coverage problems, they are limited by the complex geometry of reading, the low sensitivity to soil water content above a significant 
threshold [98], and low spatial resolution for large area analysis [99,100], which is a few centimeters of representativeness.

Another part of the uncertainty comes from the use of the Harmonized World Soil Database for the pedologic characteristics of the soils. In fact, the whole Yangtze $\backslash$ River basin (about 2 million $\mathrm{km}^{2}$ ) is included for $94.5 \%$ in one soil type. Thanks to the pixel-wise calibration methodology implemented in this work, the variability of the soil hydraulic parameters was increased, allowing a more reliable definition.

The routing parameters were calibrated by comparing the observed ground volumes with modeled volumes at different river cross-sections. Discharges were simulated with errors of $7.3 \%$ to $15 \%$ on volumes. These results should be analyzed considering also that ground discharge measures could be affected by considerable uncertainty, ranging from $8 \%$ to $20 \%$ according to the review of 140 publications by [101] or from $6.2 \%$ to $42.8 \%$ in the Po River basin in Italy, as analyzed by [102]. These problems in the Yangtze River basin are also accentuated by the presence of the Three Gorges Dam and several dams whose regulations are almost unknown. Similar performances of the FEST-EWB model have been also obtained in the Po River basin [5] and in the Valencia River [103].

The lake dynamics were also calibrated in the FEST-EWB model by comparing water heights from satellite altimeter data and the water area from satellite data. Errors on the water area extent of $6 \%$ and $9 \%$, and errors on the water level of $-3.6 \%$ and $3 \%$ were obtained for Poyang and Dongting Lakes, respectively. These results should be analyzed considering two sources of errors: (1) Altimeter data, which were provided with uncertainties ranging between 10 and $1.5 \mathrm{~m}$ [50]; and (2) lake extent definition due to the presence of several wetlands area, especially in Poyang Lake.

The accuracy of the model calibration methodology may also be analyzed considering the different optimization techniques, based on different objective functions as RMSE or the Nash-Sutcliffe criterion and on different minimization techniques with a local gradient or a global method [104,105]. In this paper, a "trial and error" approach was used, which is a simple non-automatic method based on repeated and varied attempts, which, however, allows testing of only congruent parameter combinations within their physical values until the errors do not change anymore. Of course, this may introduce the problem of equifinality, which is embedded in all techniques and hydrological models [106].

Author Contributions: Conceptualization, C.C. and M.M.; methodology, C.C. and M.M.; validation, C.C.; formal analysis, C.C., C.H.; investigation, C.C. and M.M., Z.S.; data curation, C.C., C.H., Y.H.; writing-original draft preparation, C.C., H.Y.; writing-review and editing, M.M., H.Y., Z.S.; supervision, M.M., Z.S.; project administration and funding acquisition, M.M.

Funding: This work was realized within the framework of the Sino-European joint research DRAGON2 and DRAGON3 from the ESA and Chinese MOST initiative.

Acknowledgments: Thanks to Mauro Colombo and Mattia Bergamini who helped during their master thesis at Politecnico di Milano. Thanks to the anonymous reviewers and the editor for their comments who helped to improve the paper.

Conflicts of Interest: The authors declare no conflict of interest.

\section{References}

1. Ceola, S.; Montanari, A.; Krueger, T.; Dyer, F.; Kreibich, H.; Westerberg, I.; Carr, G.; Cudennec, C.; Elshorbagy, A.; Savenije, H.; et al. Adaptation of water resources systems to changing society and environment: A statement by the International Association of Hydrological Sciences. Hydrol. Sci. J. 2016, 61, 2803-2817. [CrossRef]

2. Sivapalan, M. From engineering hydrology to Earth system science: Milestones in the transformation of hydrologic science. Hydrol. Earth Syst. Sci. 2018, 22, 1665-1693. [CrossRef]

3. Oki, T.; Kanae, S. Global hydrological cycles and world water resources. Science 2006, 313, $1068-1072$. [CrossRef]

4. Pan, M.; Wood, E.F. Data assimilation for estimating the terrestrial water budget using a constrained ensemble Kalman filter. J. Hydrometeorol. 2006, 7, 534-547. [CrossRef] 
5. Rabuffetti, D.; Ravazzani, G.; Corbari, C.; Mancini, M. Verification of operational Quantitative Discharge Forecast (QDF) for a regional warning system-the AMPHORE case studies in the upper Po River. Nat. Hazards Earth Syst. Sci. 2008, 8, 1-13. [CrossRef]

6. McMillan, H.; Freer, J.; Pappenberger, F.; Krueger, T.; Clark, M. Impacts of uncertain river flow data on rainfall-runoff model calibration and discharge predictions. Hydrol. Processes Int. J. 2010, 24, 1270-1284.

7. Refsgaard, J.C. Discussion of model validation in relation to the regional and global scale. In Model Validation: Perspectives in Hydrological Science; Anderson, M.G., Bates, P.D., Eds.; Wiley: New York, NY, USA, 2001; pp. 461-483.

8. McCabe, M.F.; Wood, E.F.; Wójcik, R.; Pan, M.; Sheffield, J.; Gao, H.; Su, H. Hydrological consistency using multi-sensor remote sensing data for water and energy cycle studies. Remote Sens. Environ. 2008, 112, 430-444. [CrossRef]

9. Rodell, M.; Famiglietti, J.S.; Chen, J.; Seneviratne, S.I.; Viterbo, P.; Holl, S.; Wilson, C.R. Basin scale estimates of evapotranspiration using GRACE and other observations. Geophys. Res. Lett. 2004, 31, L20504. [CrossRef]

10. Ramillien, G.; Frappart, F.; Güntner, A.; Ngo-Duc, T.; Cazenave, A.; Laval, K. Time variations of the regional evapotranspiration rate from Gravity Recovery and Climate Experiment (GRACE) satellite gravimetry. Water Resour. Res. 2006, 42, W10403. [CrossRef]

11. Sheffield, J.; Ferguson, C.; Troy, T.; Wood, E.F.; McCabe, M. Closing the terrestrial water budget from satellite remote sensing. Geophys. Res. Lett. 2009, 36. [CrossRef]

12. Gao, H.; Tang, Q.; Ferguson, C.R.; Wood, E.F.; Lettermaier, D.P. Estimating the water budget of major US river basins via remote sensing. Int. J. Remote Sens. 2010, 31, 3955-3978. [CrossRef]

13. Caparrini, F.; Castelli, F.; Entekhabi, D. Estimation of surface turbulent fluxes through assimilation of radiometric surface temperature sequences. J. Hydrometeorol. 2004, 5, 145-159. [CrossRef]

14. Famiglietti, J.S.; Wood, E.F. Multiscale modelling of spatially variable water and energy balance processes. Water Resour. Res. 1994, 30, 3061-3078. [CrossRef]

15. Corbari, C.; Sobrino, J.A.; Mancini, M.; Hidalgo, V. Land surface temperature representativeness in a heterogeneous area through a distributed energy-water balance model and remote sensing data. Hydrol. Earth Syst. Sci. 2010, 14, 2141-2151. [CrossRef]

16. Liang, X.; Lettenmaier, D.P.; Wood, E.F.; Burges, S.J. A simple hydrologically based model of land surface water and energy fluxes for GCMs. J. Geophys. Res. Atmos. 1994, 99, 14415-14428. [CrossRef]

17. Crow, W.T.; Wood, E.F. The assimilation of remotely sensed soil brightness temperature imagery into a land-surface model using ensemble Kalman filtering: A case study based on ESTAR measurements during SGP97. Adv. Water Resour. 2003, 26, 137-149. [CrossRef]

18. Kumar, P.; Kaleita, A.L. Assimilation of Surface Temperature in a Land-Surface Model, Remote Sensing and Hydrology. In Proceedings of the Symposium Held at Santa Fe, Santa Fe, NM, USA, 28 June-2 July 1999; IAHS Publication no. 267.

19. Huang, Y.; Salama, M.S.; Su, Z.; Zheng, D.; Krol, M.S.; Hoekstra, A.Y.; Zhou, Y. Effects of Roughness Length Parameterizations on Regional-Scale Land Surface Modeling of Alpine Grasslands in the Yangtze River Basin. J. Hydrometeorol. 2016, 17, 1069-1085. [CrossRef]

20. Fang, Y.-H.; Zhang, X.; Corbari, C.; Mancini, M.; Niu, G.-Y.; Zeng, W. Improving the Xin'anjiang Hydrological Model Based on Mass-Energy Balance. Hydrol. Earth Syst. Sci. 2017, 21, 3359-3375.

21. Immerzeel, W.W.; Droogers, P. Calibration of a distributed hydrological model based on satellite evapotranspiration. J. Hydrol. 2008, 349, 411-424. [CrossRef]

22. Campo, L.; Caparrini, F.; Castelli, F. Use of multi-platform, multi-temporal remote-sensing data for calibration of a distributed hydrological model: An application in the Arno basin, Italy. Hydrol. Processes Int. J. 2006, 20, 2693-2712. [CrossRef]

23. Rientjes, T.H.M.; Muthuwatta, L.P.; Bos, M.G.; Booij, M.J.; Bhatti, H.A. Multi-variable calibration of a semi-distributed hydrological model using streamflow data and satellite-based evapotranspiration. J. Hydrol. 2013, 505, 276-290. [CrossRef]

24. Wanders, N.; Karssenberg, D.; De Roo, A.; de Jong, S.M.; Bierkens, M.F.P. The suitability of remotely sensed soil moisture for improving operational flood forecasting. Hydrol. Earth Syst. Sci. 2014, 18, 2343-2357. [CrossRef]

25. Su, Z. The Surface Energy Balance System (SEBS) for estimation of turbulent heat fluxes. Hydrol. Earth Syst. Sci. 2002, 6, 85-99. [CrossRef] 
26. Roerink, G.J.; Su, Z.; Menenti, M. S-SEBI: A simple remote sensing algorithm to estimate the surface energy balance. Phys. Chem. Earth Part B Hydrol. Oceans Atmos. 2000, 25, 147-157. [CrossRef]

27. Norman, J.M.; Kustas, W.P.; Humes, K.S. Source approach for estimating soil and vegetation energy fluxes in observations of directional radiometric surface temperature. Agric. For. Meteorol. 1995, 77, 263-293. [CrossRef]

28. Bastiaanssen, W.G.M.; Menenti, M.; Feddes, R.A.; Holtslag, A.A.M. A remote sensing surface energy balance algorithm for land (SEBAL), 1. Formulation. J. Hydrol. 1998, 212, 198-212. [CrossRef]

29. Gutmann, E.D.; Small, E.E. A method for the determination of the hydraulic properties of soil from MODIS surface temperature for use in land-surface models. Water Resour. Res. 2010, 46. [CrossRef]

30. Corbari, C.; Mancini, M.; Li, J.; Su, Z. Can satellite land surface temperature data be used similarly to ground discharge measurements for distributed hydrological model calibration? Hydrol. Sci. J. 2015, 60, 202-217. [CrossRef]

31. Corbari, C.; Mancini, M. Calibration and validation of a distributed energy water balance model using satellite data of land surface temperature and ground discharge measurements. J. Hydrometeorol. 2014, 15, 376-392. [CrossRef]

32. Alsdorf, D.E.; Rodriguez, E.; Lettenmaier, D.P. Measuring surface water from space. Rev. Geophys. 2007, 45, RG2002. [CrossRef]

33. Schumann, G.; Bates, P.D.; Horritt, M.S.; Matgen, P.; Pappenberger, F. Progress in integration of remote sensing derived flood extent and stage data and hydraulic models. Rev. Geophys. 2009, 47, RG4001. [CrossRef]

34. Marcus, W.A.; Fonstad, M.A. Optical remote mapping of rivers at sub-meter resolutions and watershed extents. Earth Surf. Processes Landf. 2008, 33, 4-24. [CrossRef]

35. Smith, L.C. Satellite remote sensing of river inundation area, stage, and discharge: A review. Hydrol. Processes 1997, 11, 1427-1439. [CrossRef]

36. Bwangoy, J.B.; Hansen, M.C.; Roya, D.P.; Grandi, G.D.; Justic, C.O. Wetland mapping in the Congo Basin using optical and radar remotely sensed data and derived topographical indices. Remote Sens. Environ. 2010, 114, 73-86. [CrossRef]

37. Brakenridge, R.; Anderson, E. MODIS-based flood detection, mapping and measurement: The potential for operational hydrological applications. In Transboundary Floods: Reducing the Risks Through Flood Management; Springer: New York, NY, USA, 2006; pp. 1-12.

38. Peng, D.; Xiong, L.; Guo, C.; Shu, N. Study of Dongting Lake area variation and its influence on water level using MODIS data. Hydrol. Sci. J. 2005, 50, 31-44. [CrossRef]

39. Yésou, H.; Huber, C.; Lai, X.; Averty, S.; Li, J.; Daillet, S.; Bergé-Nguyen, M.; Chen, X.; Huang, S.; Burnham, J.; et al. Nine years of monitoring of water resource over the Yangtze middle reaches exploiting ENVISAT, MODIS, Beijing 1 time series, altimetric data, and field measurements. Lake Reserv. Manag. 2011, 16, 231-247.

40. Yesou, H.; Pottier, E.; Mercier, G.; Grizonnet, M.; Haouet, S.; Giros, A.; Faivre, R.; Maxant, J.; Studer, M.; Huber, C. Synergy of Sentinel1 and Sentinel2 imagery for wetland monitoring information extraction from continuous flow of Sentinel images applied to water bodies and vegetation mapping and monitoring. In Proceedings of the Geoscience and Remote Sensing (IGARSS), IEEE International Symposium, Beijing, China, 10-15 July 2016; pp. 163-165.

41. Yésou, H.; HUBER, C.; HAOUET, S.; LAI, X.; HUANG, S.; de FRAIPONT, P.; DESNOS, Y.L. Exploiting Sentinel1 time series to monitor the largest fresh water bodies in PR China, the Poyang lake case. In Proceedings of the 2016 IEEE International Geoscience and Remote Sensing Symposium (IGARSS), Beijing, China, 10-15 July 2016; pp. 36882-36885.

42. Yésou, H.; Huber, C.; Huang, S.; Studer, M.; Lai, X.; Chen, X.; Daillet, S. Water resource monitoring based on EO data: Gained experience after 10 years of DRAGON programme over the Yangtze middle reaches: From ERS1 to Sentinel 1, and from MERIS to HJ and Pleiades HR. In Proceedings of the Mid Term Results of Dragon III, Chengdu, China, 26-28 May 2014. ESA SPS 742.

43. Prigent, C.; Matthews, E.; Aires, F.; Rossow, W. Remote sensing of global wetland dynamics with multiple satellite data sets. Geophys. Res. Lett. 2001, 28, 4631-4634. [CrossRef]

44. Mason, D.C.; Horritt, M.S.; Dall'Amico, J.T.; Scott, T.R. Improving River Flood Extent Delineation from Synthetic Aperture Radar Using Airborne Laser Altimetry. IEEE Trans. Geosci. Remote Sens. 2007, 45, 3932-3943. [CrossRef] 
45. Long, S.; Fatoyinbo, T.E.; Policelli, F. Flood extent mapping for Namibia using change detection and thresholding with SAR. Environ. Res. Lett. 2014, 9, 035002. [CrossRef]

46. Wingham, D.J.; Rapley, C.G. Saturation effects in the Seasat altimeter receiver. Int. J. Remote Sens. 1987, 8 , 1163-1173. [CrossRef]

47. Morris, C.S.; Gill, S.K. Evaluation of the TOPEX/POSEIDON altimeter system over the Great Lakes. J. Geophys. Res. Oceans 1994, 99, 24527-24539. [CrossRef]

48. Birkett, C.M. Contribution of the Topex NASA radar altimeter to the global monitoring of large rivers and wetlands. Water Resour. Res. 2004, 34, 1223-1239. [CrossRef]

49. Berry, P.A.M.; Garlick, J.D.; Freeman, J.A.; Mathers, E.L. Global inland water monitoring from multi-mission altimetry. Geophys. Res. Lett. 2005, 32, L16401. [CrossRef]

50. Cretaux, J.-F.; Jelinski, W.; Calmant, S.; Kouraev, A.; Vuglinski, V.; Berge-Nguyen, M.; Gennero, M.-C.; Nino, F.; Abarca Del Rio, R.; Cazenave, A.; et al. SOLS: A lake database to monitor in the Near Real Time water level and storage variations from remote sensing data. Adv. Space Res. 2001, 47, 1497-1507. [CrossRef]

51. Frappart, F.; Calmant, S.; Cauhope, M.; Seyler, F.; Cazenave, A. Preliminary results of ENVISAT RA-2-derived water levels validation over the Amazon basin. Remote Sens. Environ. 2006, 100, 252-264. [CrossRef]

52. Leon, J.G.; Calmant, S.; Seyler, F.; Bonnet, M.-P.; Cauhopé, M.; Frappart, F.; Filizola, N.; Fraizy, P. Rating curves and estimation of average water depth at the upper Negro River based on satellite altimeter data and modeled discharges. J. Hydrol. 2006, 328, 481-496. [CrossRef]

53. Getirana, A.C.V.; Peters-Lidard, C. Estimating water discharge from large radar altimetry datasets. Hydrol. Earth Syst. Sci. 2013, 17, 923-933. [CrossRef]

54. Paris, A.; Dias de Paiva, R.; Santos daSilva, J.; Medeiros Moreira, D.; Calmant, S.; Garambois, P.-A.; Collischonn, W.; Bonnet, M.-P.; Seyler, F. Stage-discharge rating curves based on satellite altimetry and modeled discharge in the Amazon basin. Water Resour. Res. 2016, 52, 3787-3814. [CrossRef]

55. Tarpanelli, A.; Barbetta, S.; Brocca, L.; Moramarco, T. River discharge estimation by using altimetry data and simplified flood routing modeling. Remote Sens. 2013, 5, 4145-4162. [CrossRef]

56. Getirana, A.C.V. Integrating spatial altimetry data into the automatic calibration of hydrological models. J. Hydrol. 2010, 387, 244-255. [CrossRef]

57. Birkinshaw, S.J.; O’Donnell, G.M.; Moore, P.; Kilsby, C.G.; Fowler, H.J.; Berry, P.A.M. Using satellite altimetry data to augment flow estimation techniques on the Mekong River. Hydrol. Processes 2010, 24, 3811-3825. [CrossRef]

58. Biancamaria, S.; Bates, P.D.; Boone, A.; Mognard, N.M. Large-scale coupled hydrologic and hydraulic modelling of an arctic river: The Ob river in Siberia. J. Hydrol. 2009, 379, 136-150. [CrossRef]

59. Domeneghetti, A.; Tarpanelli, A.; Brocca, L.; Barbetta, S.; Moramarco, T.; Castellarin, A.; Brath, A. The use of remote sensing-derived water surface data for hydraulic model calibration. Remote Sens. Environ. 2014, 149, 130-141. [CrossRef]

60. Corbari, C.; Ravazzani, G.; Mancini, M. A distributed thermodynamics model for energy and mass balance computation: FEST-EWB. Hydrol. Processes 2011, 25, 1443-1452. [CrossRef]

61. Ge, Y.; Xu, W.; Gu, Z.H.; Zhang, Y.C.; Chen, L. Risk perception and hazard mitigation in the Yangtze River Delta region, China. Nat. Hazards 2011, 56, 633-648. [CrossRef]

62. Shankman, D.; Keim, B.D.; Song, J. Flood Frequency in China's Poyang Lake Region: Trends and Teleconnections. Int. J. Climatol. J. R. Meteorol. Soc. 2006, 26, 1255-1266. [CrossRef]

63. Zhang, Q.; Liu, C.; Xu, C.; Xu, Y.; Jiang, T. Observed trends of annual maximum water level and streamflow during past 130 years in the Yangtze River basin, China. J. Hydrol. 2006, 324, 255-265. [CrossRef]

64. Wang, J.; Sheng, Y.; Gleason, J.C.; Wada, Y. Downstream Yangtze River levels impacted by Three Gorges Dam. Environ. Res. Lett. 2013, 8, 044012. [CrossRef]

65. Mei, X.; Dai, Z.; van Gelder, P.H.A.J.M.; Gao, J. Linking Three Gorges Dam and downstream hydrological regimes along the Yangtze River, China. Earth Space Sci. 2015, 2, 94-106. [CrossRef]

66. Guo, H.; Hu, Q.; Zhang, Q.; Feng, S. Effects of the Three Gorges Dam on Yangtze River flow and river interaction with Poyang Lake, China: 2003-2008. J. Hydrol. 2012, 416-417, 19-27. [CrossRef]

67. Hu, B.; Yang, Z.; Wang, H.; Sun, X.; Bi, N. Sedimentation in the Three Gorges Dam and its impact on the sediment flux from the Changjiang (Yangtze River), China. Hydrol. Earth Syst. Sci. Discuss. 2009, 6, 5177-5204. [CrossRef] 
68. Yang, S.; Zhang, J.; Xu, X. Influence of the Three Gorges Dam on downstream delivery of sediment and its environmental implications, Yangtze River. Geophys. Res. Lett. 2007, 34, L10401. [CrossRef]

69. Yao, J.; Zhang, Q.; Li, Y.; Li, M. Hydrological evidence and causes of seasonal low water levels in a large river-lake system: Poyang Lake, China. Hydrol. Res. 2016, 47, 24-39. [CrossRef]

70. Hu, Q.; Feng, S.; Guo, H.; Chen, G.; Jiang, T. Interactions of the Yangtze River flow and hydrologic processes of the Poyang Lake, China. J. Hydrol. 2007, 347, 90-100. [CrossRef]

71. Huber, C.; Chen, X.; Li, J.; Lai, X.; Daillet, S.; Li, C.; Huang, S.; Burnham, J.; Uribe, C.; Zhang, W.; et al. Twelve Years of Monitoring from Space the Largest Chinese lakes: Gained Experience in Term of Water Resource, Biodiversity and Public Health and Recommendations in Term of EO Data Resource Access. ESA MOST. In Proceedings of the Dragon Final Symposium, Beijing, China, 25-29 June 2012. ESA SP. 704.

72. Feng, L.; Hu, C.; Chen, X.; Cai, X.; Tian, L.; Gan, W. Assessment of inundation changes of Poyang Lake using MODIS observations between 2000 and 2010. Remote Sens. Environ. 2012, 121, 80-92. [CrossRef]

73. Zhang, Z.; Chen, X.; Xu, C.; Hong, Y.; Hardy, J.; Sun, Z. Examining the influence of river-lake interaction on the drought and water resources in the Poyang Lake basin. J. Hydrol. 2015, 522, 510-521. [CrossRef]

74. Hui, F.; Xu, B.; Huang, H.; Yu, Q.; Gong, P. Modelling spatial-temporal change of Poyang Lake using multitemporal Landsat imagery. Int. J. Remote Sens. 2008, 29, 5767-5784. [CrossRef]

75. ZHANG, J.; XU, K.; YANG, Y.; QI, L.; HAYASHI, S.; WATANABE, M. Measuring water storage fluctuations in lake Dongting, china, by topex/poseidon satellite altimetry. Environ. Monit. Assess. 2006, 115, $23-37$. [CrossRef]

76. Zhao, S.; Fang, J.; Miao, S.; Gu, B.; Tao, S.; Peng, C.; Tang, Z. The 7-Decade Degradation of a Large Freshwater Lake in Central Yangtze River, China. Environ. Sci. Technol. 2005, 39, 431-436. [CrossRef]

77. Huang, Q.; Jiang, J.; Yesou, H.; Lai, X. The Change Analysis of Wetland Landscape Based on Remote Sensing Data in Dongting Lake, China. In Proceedings of the Dragon 2 Final Results and Dragon 3 Kickoff Symposium, Beijing, China, 25-29 June 2012; ESA SP-704. ISBN 92-9092-268-1.

78. Hu, C.; Fang, C.; Cao, W. Shrinking of Dongting Lake and its weakening connection with the Yangtze River: Analysis of the impact on flooding. Int. J. Sediment Res. 2015, 30, 256-262. [CrossRef]

79. Yang, K.; He, J.; Tang, W.; Qin, J.; Cheng, C.C.K. On downward shortwave and longwave radiations over high altitude regions: Observation and modeling in the Tibetan Plateau. Agric. For. Meteorol. 2010, 150, 38-46. [CrossRef]

80. Harmonized World Soil Database (version 1.1); FAO: Rome, Italy; IIASA: Laxenburg, Austria, 2009; Available online: https://webarchive.iiasa.ac.at/Research/LUC/External-World-soil-database/HTML/ (accessed on 1 January 2009).

81. Rawls, W.J.; Brakensiek, D.L. Prediction of Soil Water Properties for Hydrologic Modelling. In Proceedings of the Symposium Watershed Management in the Eighties, New York, NY, USA, 30 April-1 May 1985; Jones, E.B., Ward, T.J., Eds.; pp. 293-299.

82. Arino, O.; Gross, D.; Ranera, F.; Bourg, L.; Leroy, M.; Bicheron, P.; Latham, J.; Di Gregorio, A.; Brockman, C.; Witt, R.; et al. GlobCover: ESA service for global land cover from MERIS. In Proceedings of the 2007 IEEE International Geoscience and Remote Sensing Symposium, Barcelona, Spain, 23-28 July 2007.

83. Andreoli, R.; Yésou, Y.; Li, J.; Desnos, Y.-L.; Huang, S.; . De Fraipont, P. Poyang Hu (Jiangxi Province, China) area variations between January 2004 and June 2006 using ENVISAT low and medium resolution time series. Ann. GIS 2007, 13, 24-35. [CrossRef]

84. De Leeuw, J.; Shankman, D.; Wu, G.; Boer, F.W.; Burnham, M.; He, Q.; Yesou, H.; Xiao, J. Strategic assessment of the magnitude and impacts of sand mining in Poyang lake, China. Reg. Env. Chang. 2010, 10, 95-102. [CrossRef]

85. Huber, C.; Lai, X.; Uribe, C.; Huang, S.; Marie, T.; Chen, X.; Andreoli, R.; Li, J.; Yesou, H. Influence of resolution on water detection and on the water height and level relationship, case of Poyang lake (China). In Proceedings of the ESA Living Planet Symposium, Bergen, Norway, 28 June-2 July 2010; ISBN 978-92-9221-250-6, ESA SP-686.

86. Mancini, M. La modellazione distribuita della risposta idrologica: Effetti della variabilità spaziale e della scala di rappresentazione del fenomeno dell'assorbimento. Ph.D. Thesis, Politecnico di Milano, Milan, Italy, 1990. (In Italian) 
87. Corbari, C.; Sobrino, J.A.; Mancini, M.; Hidalgo, V. Mass and energy flux estimates at different spatial resolutions in a heterogeneous area through a distributed energy-water balance model and remote sensing data. Int. J. Remote Sens. 2013, 34, 3208-3230. [CrossRef]

88. Corbari, C.; Mancini, M. Intercomparison across scales between remotely-sensed land surface temperature and representative equilibrium temperature from a distributed energy water balance model. Hydrol. Sci. J. 2014, 59, 1830-1843. [CrossRef]

89. Ravazzani, G.; Mancini, M.; Giudici, I.; Amadio, P. Effects of soil moisture parameterization on a real-time flood forecasting system based on rainfall thresholds. In Quantification and Reduction of Predictive Uncertainty for Sustainable Water Resources Management. In Proceedings of the Symposium HS2004 at IUGG2007, Perugia, Italy, 7-13 July 2007; IAHS: Wallingford, UK; pp. 407-416.

90. Chow, V.T.; Maidment, D.R.; Mays, L.W. Applied Hydrology; McGraw Hill: New York, NY, USA, $1998 ;$ p. 572.

91. Li, M.; Zhang, Q.; Li, Y.; Yao, J.; Tan, Z. Inter-annual variations of Poyang Lake area during dry seasons: Characteristics and implications. Hydrol. Res. 2016, 4, 40-50. [CrossRef]

92. Lai, X.; Jiang, J.; Liang, Q.; Huang, Q. Large-scale hydrodynamics modeling of the middle Yangtze River Basin with complex river-lake interactions. J. Hydrol. 2013, 492, 228-243. [CrossRef]

93. Dooge, J.C.I. Looking for hydrologic laws. Water Resour. Res. 1986, 22, 46-58. [CrossRef]

94. Sobrino, J.A.; Jimènez-Munoz, J.C.; Lee, B.; Gillespie, A.R.; Sabol, D.A.; Gustafson, W.T. Accuracy of ASTER Level-2 thermal-infrared Standard Products of an agricultural area in Spain. Remote Sens. Environ. 2007, 106, 146-153. [CrossRef]

95. Sobrino, J.A.; Kharraz, J.E.; Li, Z.-L. Surface temperature and water vapour retrieval from MODIS data. Int. J. Remote Sens. 2003, 24, 5161-5182. [CrossRef]

96. Brooke, J.K.; Harlow, R.C.; Scott, R.L.; Best, M.J.; Edwards, J.M.; Thelen, J.-C.; Weeks, M. Evaluating the Met Office Unified Model land surface temperature in Global Atmosphere/Land 3.1 (GA/L3.1), Global Atmosphere/Land 6.1 (GA/L6.1) and limited area $2.2 \mathrm{~km}$ configurations. Geosci. Model Dev. 2019, 12, 1703-1724. [CrossRef]

97. Ghent, D.; Kaduk, J.; Remedios, J.; Ardö, J.; Balzter, H. Assimilation of land surface temperature into the land surface model JULES with an ensemble Kalman filter. J. Geophys. Res. Atmos. 2010, 115, D19112. [CrossRef]

98. Mancini, M.; Hoeben, R.; Troch, P. Multifrequency radar observation of bare surface soil moisture content: A laboratory experiment. Water Resour. Res. 1999, 35, 1827-1838. [CrossRef]

99. Wagner, W.; Scipal, K. Large-Scale Soil Moisture Mapping in Western Africa using the ERS Scatterometer. IEEE Trans. Geosci. Remote Sens. 2000, 38, 1777-1782. [CrossRef]

100. Kerr, Y.H.; Al-Yaari, A.; Rodriguez-Fernandez, N.; Parrens, M.; Molero, B.; Leroux, D.; Bircher, S.; Mahmoodi, A.; Mialon, A.; Richaume, P.; et al. Overview of SMOS performance in terms of global soil moisture monitoring after six years in operation. Remote Sens. Environ. 2016, 180, 40-63. [CrossRef]

101. Pelletier, M.P. Uncertainties in the determination of river discharge: A literature review. Can. J. Civ. Eng. 1987, 15, 834-850. [CrossRef]

102. Di Baldassarre, G.; Montanari, A. Uncertainty in river discharge observations: A quantitative analysis. Hydrol. Earth Syst. Sci. 2009, 13, 913-921. [CrossRef]

103. Amengual, A.; Carrió, D.S.; Ravazzani, G.; Homar, V. A comparison of ensemble strategies for flash flood forecasting: The 12 october 2007 case study in Valencia, Spain. J. Hydrometeorol. 2017, 18, 1143-1166. [CrossRef]

104. Levenberg, K. A Method for the Solution of Certain Non-Linear Problems in Least Squares. Q. Appl. Math. 1994, 2, 164-168. [CrossRef]

105. Kuczera, G. Efficient subspace probabilistic parameter optimization for catchment models. Water Resour Res. 1997, 33, 177-185. [CrossRef]

106. Beven, K. Prophesy, reality and uncertainty in distributed hydrological modelling. Adv. Water Resour. 1993, 16, 41-51. [CrossRef]

(C) 2019 by the authors. Licensee MDPI, Basel, Switzerland. This article is an open access article distributed under the terms and conditions of the Creative Commons Attribution (CC BY) license (http://creativecommons.org/licenses/by/4.0/). 